DOI: $10.19195 / 0524-4544.327 .6$

\author{
JERZY KORCZAK \\ ORCID: 0000-0003-1104-4837 \\ Uniwersytet Wrocławski \\ jerzy.korczak@uwr.edu.pl
}

\title{
Stulecie polskiego prawa urzędniczego
}

\begin{abstract}
Abstrakt: W artykule przeprowadzono analizę regulacji prawnych odnoszących się do funkcjonariuszy i pracowników zatrudnionych w urzędach i jednostkach organizacyjnych administracji publicznej w Polsce w okresie od 1918 do 2018 roku. Jej wyniki wykorzystano do wskazania głównych uwarunkowań kształtowania się prawa urzędniczego w minionym stuleciu i próby oceny jego następstw.
\end{abstract}

Słowa kluczowe: prawo urzędnicze, funkcjonariusz publiczny, urzędnik, pracownik administracji.

\section{Wstęp}

W procesie odbudowy państwowości polskiej po odzyskaniu niepodległości istotną rolę odgrywały kadry administracji odradzającego się państwa. Scalanie w jeden organizm państwowy ziem należących przez ponad 120 lat do różnych państw stosujących różne modele organizacji swojej administracji, a tym samym różne modele zatrudnienia w jej urzędach i innych jednostkach organizacyjnych, nie sprzyjało ich unifikacji. Sam zapał osób wcześniej zatrudnionych w administracji państw zaborczych lub w okresie regencji czy też podejmujących zatrudnienie po raz pierwszy w nowo tworzonych strukturach organizacyjnych polskiej administracji nie wystarczał. Potrzebne były zabiegi legislacyjne, najpierw adaptujące trzy różne struktury do warunków państwa unitarnego, a następnie regulujące na nowo zasady zatrudnienia funkcjonariuszy, urzędników i pracowników administracji.

Mimo wielu zadań stojących najpierw przed Naczelnikiem Państwa, a następnie już przed pierwszym sejmem i wybranym przez niego rządem, świadomość znaczenia administracji dla funkcjonowania państwa była tak duża, że stosunkowo 
szybko, bo już w 1922 roku doszło do pierwszej istotnej regulacji w odniesieniu przynajmniej do administracji rządowej. Mimo oczekiwań przez cały okres międzywojenny nie udało się natomiast uregulować jednolitej podstawy zatrudnienia pracowników samorządowych na obszarze całego państwa. Już tylko to zestawienie dwóch grup osób zatrudnionych w administracji tego okresu zwraca uwagę na brak jednolitości w ówczesnym myśleniu o polskim prawie urzędniczym.

Ta złożoność ujawnia się jeszcze bardziej po ponownym odzyskiwaniu niepodległości, po II wojnie światowej, gdy na kształtowanie się polskiego prawa urzędniczego wywiera wpływ ideologia innego państwa - Polska, podobnie jak wiele państw Europy Środkowo-Wschodniej, zależna jest wówczas od Związku Sowieckiego, w którym zatrudnienie w administracji państwowej podporządkowano celom politycznym, a nie zasadom prawa. Obserwować można coraz bardziej odczuwalne odchodzenie od publicznego charakteru zatrudnienia na stanowiskach urzędniczych na rzecz dominacji prawa pracy i formy nawiązania stosunku już nie tyle służbowego, co stosunku pracy na podstawie umowy o pracę. Kulminacyjnym momentem tego procesu było oczywiście przyjęcie ustawy kodeksu pracy w 1974 roku. Tylko w niewielkim zakresie tendencję tę przełamała ustawa o pracownikach urzędów państwowych z 1982 roku, przywracając mianowanie, ale wyłącznie jako formę nawiązania stosunku pracy.

Nawet po transformacji ustrojowej z początku lat 90 . XX wieku, mimo że doszło do przyjęcia pierwszej ustawy o pracownikach samorządowych oraz przywrócenia w 1996 roku korpusu służby cywilnej, ów prywatnoprawny charakter zatrudnienia poza stosunkami służbowymi w służbach mundurowych pozostał już stałą cechą charakterystyczną tej sfery regulacji prawnej. Rzutuje to nie tylko na jej status - omawiana sfera bowiem, w odróżnieniu od tradycji europejskiej, w Polsce nie stanowi samodzielnej gałęzi prawa - ale także na stan doktryny, w którym jeśli w ogóle nie kwestionuje się odrębności prawa urzędniczego, to z reguły poza naukami administracyjnymi traktuje się je jako część doktryny prawa pracy.

\section{Korzenie polskiego prawa urzędniczego}

Prawo urzędnicze rodziło się na początku XVIII wieku w królestwie pruskim, gdy Fryderyk Wilhelm I doszedł do wniosku, że potęgę swego państwa zbudować może nie tylko przez stworzenie silnej armii oraz warunków dla rozwoju gospodarki, ale jego wewnętrzną organizację, której fundamentem miała stać się nowoczesna administracja. Jako jeden z pierwszych monarchów w reskrypcie z 1710 roku ustanowił jako warunek objęcia stanowiska w urzędzie królewskiej administracji wykazanie się wykształceniem administracyjnym, a nie jak dotąd jedynie pochodzeniem z określonej grupy społecznej czy zasługami na polu walki. 
To z tego powodu zyskał w doktrynie niemieckiej miano Vater der Berufstbeamtentums. Jego dzieło kontynuowali następcy: Fryderyk II, zwany Wielkim, i Fryderyk Wilhelm II, zwłaszcza przez odpowiednie regulacje dotyczące zatrudnienia urzędników pruskiego państwa w Allgemeine Landrecht für preußischen Staaten ${ }^{1}$. Prusy i pozostałe państwa niemieckie a ostatecznie Cesarstwo Niemieckie przez cały XIX wiek rozwijały prawo urzędnicze, nadając charakter publicznoprawny stosunkowi łączącemu urzędnika z państwem. W systemie niemieckiego prawa aż do czasów współczesnych prawo urzędnicze (Beamtenrecht) stanowi odrębną i samodzielną gałąź prawa, ukształtowała się także samodzielna i odrębna doktryna tego prawa.

Państwa europejskie w ślad za pruskimi doświadczeniami przez naśladownictwo oraz własne rodzime rozwiązania, jak chociażby we Francji, tworzyły własne prawo urzędnicze. Do tego grona pod koniec XVIII wieku dołącza Polska, przyjmując w wykonaniu uchwalonego Prawa o miastach Ustawę z dnia 30 czerwca 1791 roku „Urządzenie wewnętrzne miast wolnych Rzeczypospolitej w Koronie i Wielkim Xięstwie Litewskim"2, w której po raz pierwszy ustanawiany jest katalog stanowisk urzędniczych w magistratach wraz z wymaganiami kwalifikacyjnymi, uprawnieniami w zakresie wynagrodzenia oraz zakresem odpowiedzialności wraz z jej stopniowalnymi w zależności od rodzaju deliktu służbowego środkami nakładanymi w postępowaniu przed sądami Komisji Policji (art. IX i X). Upadek I Rzeczypospolitej przerywa proces aplikacji wszystkich reform Sejmu Czteroletniego, w tym oczywiście funkcjonowania magistratów, a tym samym stosowanie pierwszego aktu rodzącego się polskiego prawa urzędniczego.

Krótkotrwały okres funkcjonowania Księstwa Warszawskiego przyniósł kolejne akty polskiego prawa urzędniczego. Już w ustawie konstytucyjnej Księstwa $^{3}$ w art. 6 zdanie drugie oraz art. 82 ustalono powoływanie i odwoływanie urzędników przez króla oraz wymóg obywatelstwa dla objęcia urzędu, a następnie dekretem z dnia 29 kwietnia 1808 roku ustanowiono komisje egzaminacyjne dla urzędników administracyjnych ${ }^{4}$. Dekretem z 14 grudnia 1808 roku ustanowiono Główną Izbę Obrachunkową z jej prezesem, 2 konsyliarzami, asesorami, rachmistrzami i referentami ${ }^{5}$, wreszcie dekret $\mathrm{z}$ dnia 7 lutego 1809 roku ustanawiający organizację władz administracyjnych departamentowych i powiatowych ${ }^{6}$, podobnie jak dekret z dnia 23 lutego 1809 roku o tymczasowej organizacji gmin

1 Dostępny w 4 częściach wydanych nakładem Gottfrieda Carla Naucka w 1804 r., w Berlinie, wersja cyfrowa: https://digital.staatsbibliothek-berlin.de/suche?queryString=PPN646281224 (dostęp: 30.06.2018).

2 Volumina Legum, t. 9, 337, s. 291-297.

3 Ustawa konstytucyjna Księstwa Warszawskiego z dnia 22 lipca 1807 r. (Dz.Pr.K.W. z 1810 r. Nr 1, s. 2-47).

4 Dz.Pr.K.W. z 1810 r. Nr 4, s. 74-77.

5 Dz.Pr.K.W. z 1810 r. Nr 6, s. 120-136.

${ }^{6}$ Dz.Pr.K.W. z 1810 r. Nr 8, s. 165-186. 
miejskich i wiejskich ${ }^{7}$, ustalały ogólny ustrój administracji oraz stanowisk urzędniczych i zasady ich obejmowania.

Zakończenie bytu państwowego Księstwa Warszawskiego w Akcie Końcowym Kongresu Wiedeńskiego z dnia 9 czerwca 1815 roku było jedynie formalnym potwierdzeniem upadku państwa i zajęcia jego ziem przez carskiego okupanta w marcu 1813 roku, ponownie doprowadzając do rozbioru ziem polskich ${ }^{8}$. Od tego momentu Polacy zamieszkujący ziemie każdego z zaborów podlegali wyłącznie prawodawstwu zaborcy, w tym także jego aktom z zakresu prawa urzędniczego ${ }^{9}$. Na tym tle uwagę zwraca jeden, szczególnie dedykowany Królestwu Polskiemu, czyli ziemiom zaboru rosyjskiego. Otóż car Aleksander II wydał dnia 10 marca 1859 roku ustawę o służbie cywilnej w Królestwie Polskim ${ }^{10}$, która w 211 artykułach poza przepisami końcowymi (art. 204-211) regulowała (w trzech częściach, a każda $\mathrm{z}$ nich w tytułach dzielonych na rozdziały) bardzo szczegółowo uprawnienie do wstępowania do służby (art. 1-4), tryb przyjmowania do służby i wymagania z tym związane (art. 5-19), odbywanie aplikacji (art. 20-26), zasady awansowania (art. 27-42), przenoszenia i zwalniania urzędników (art. 43-52), uprawnienia do nawiązywania stosunku służbowego i jego zmiany (art. 53-59), obowiązki urzędników (art. 60-74), odpowiedzialność służbową i zawieszenie w urzędowaniu (art. 75-83), uprawnienia urzędników (art. 84-100), rangi urzędników (art. 101-105), zwierzchności stanowisk (art. 106-111), uposażenie urzędników (art. 112-145), urlopy urzędników (art. 146-160), wydalenie ze służby (art. 161167), dowody pełnienia służby w postaci patentów nominacyjnych, ewidencjonowania stanu służby i atestów wydawanych zwalnianym ze służby (art. 168-183),

7 Dz.Pr.K.W. z 1810 r. Nr 9, s. 201-209.

8 Zob. A. Bereza, Pozycja monarchy w Księstwie Warszawskim, „Studia Iuridica Lublinensia” 2012, nr 18, s. 9-21; J. Koredczuk, Zwiazek reform prawa cywilnego z reformami administracyjnymi w Księstwie Warszawskim, [w:] Cywilizacja administracji publicznej. Ksiega jubileuszowa z okazji 80-lecia urodzin prof. nadzw. UWr dra hab. Jana Jeżewskiego, red. J. Korczak, „Prace Naukowe Wydziału Prawa Administracji i Ekonomii Uniwersytetu Wrocławskiego. Seria: e-Monografie” 2018, nr 115, s. 233-241.

9 Można odwołać się do bogatej literatury niemieckiej analizującej administrację pruską w Wielkopolsce - M. Laubert, Die Verwaltung der Provinz Posen 1815-1847, Breslau 1923; A. Lotz, Geschichte des deutschen Beamtentums, Berlin 1914; J. Kozłowski, Administracja Wielkopolski pod pruskim zaborem 1793-1918, Poznań 2000, jak również do Gesetz, betreffend die Rechtsverhältnisse der Rechsbeamten vom 31. März 1873 (DRB B. 1873, Nr. 10, s. 61-90). W Galicji obowiązywało m.in. Verordnung der Minister des Innern und der Justiz vom 17. Märtz 1855, wirksam für alle Kronländer, mit Ausnahme des Lombardischvenetianischen Königreiches und der Militärgränze, womit die Amstinstruction für die rein politischen und für die gemischten Bezirks- und Stuhlrichterämter erlassen wird, „Reichs-Gesetz-Blatt für das Kaiserthum Oesterreich” 1855, t. 15, nr 52, s. 337) [Instrukcja urzędowa dla mieszanych i politycznych urzędów powiatowych i organów sądowych wprowadzona rozporządzeniem ministrów spraw wewnętrznych i sprawiedliwości z dnia 17 marca $1855 \mathrm{r}$.], zaś przed ostatecznym rozpadem cesarstwa w całym państwie austro-węgierskim Ustawa z dnia 25 stycznia 1914 r. o stosunkach służbowych urzędników państwowych i służby państwowej (Dz.U.P. Cz. VIII, Nr 15, s. 87-116).

${ }^{10}$ Dz.Pr. Kr.P. Nr 162, t. 53. 
rozkazy i decyzje dotyczące organizacji służby (art. 184-189), wyznaczanie do pełnienia służby obywatelskiej (art. 190-203).

Wybuch I wojny światowej wraz z działaniami na poszczególnych fragmentach ziem polskich, jak też zmiana położenia frontów i rozmieszczenia władz wojskowych, wpływały bieżąco na funkcjonowanie administracji oraz zatrudnianie w niej urzędników i pozostałych pracowników. Sytuacja po wydaniu przez niemieckie i austro-węgierskie władze okupacyjne patentu z dnia 12 września 1917 roku w sprawie władzy państwowej w Królestwie Polskim ${ }^{11}$ pozwoliła Radzie Regencyjnej sprawować władzę prawodawczą, co dotyczyło także prawa urzędniczego. Na tej podstawie, Dekret Rady Regencyjnej o tymczasowej organizacji Władz Naczelnych w Królestwie Polskim ${ }^{12}$ z 3 stycznia 1918 roku przewidział w art. 31-40 zasady zatrudniania urzędników państwowych w drodze mianowania odpowiednio przez Radę Regencyjną (wyższych — art. 31) i ministrów (pozostałych urzędników w ministerstwach - art. 32). Ich ograniczenie podmiotowe wynikało z przejściowego charakteru warunków, w jakich Rada Regencyjna sprawowała władzę, choć kolejnym dekretem określono zasady składania przysięgi przez mianowanych urzędników ${ }^{13}$, a w dalszej kolejności wydano tymczasowe przepisy dla urzędników państwowych ${ }^{14}$. Zwłaszcza reskrypt zawierający tymczasowe przepisy odegrał duże znaczenie $\mathrm{z}$ uwagi na ujęcie $\mathrm{w}$ jego 46 przepisach najważniejszych instytucji prawa urzędniczego, podkreślając publicznoprawny charakter stosunku prawnego urzędnika do państwa (art. 1) ze wszystkimi jego następstwami, gdy idzie o obowiązek lojalności wobec władzy państwowej (art. 2 i 3), ustalał zasady wstąpienia do służby (tytuł II), obowiązki i prawa urzędników (tytuł III i IV), odpowiedzialność urzędników (tytuł V), a wreszcie zasady i tryb rozwiązania stosunku służbowego (tytuł VI).

\section{Prawo urzędnicze w latach 1918-1922}

Opisany wyżej stan faktyczny stanowił punkt odniesienia dla początków odradzającego się Państwa Polskiego. W obliczu najistotniejszych dla bytu państwowego spraw w początkowym okresie sprawowania władzy przez Naczelnika Państwa nie występowały akty dotyczące tworzenia nowego prawa urzędniczego, nie licząc tak incydentalnych przepisów, jak art. 6 i 7 dekretu z 29 listopada

11 Dziennik Urzędowy Departamentu Sprawiedliwości Tymczasowej Rady Stanu Królestwa Polskiego Nr 5, Dział 2, s. 235.

12 Dz.U. Nr 1, poz. 1.

13 Dekret z dnia 20 lutego 1918 r. Rady Regencyjnej w przedmiocie przysięgi dla ministrów, urzędników, sędziów i adwokatów (Dz.U. Nr 4, poz. 6).

14 Reskrypt Rady Regencyjnej z dnia 11 czerwca 1918 r. tymczasowe przepisy służbowe dla urzędników państwowych i Tabela płac urzędników państwowych (Dz.U. Nr 6, poz. 13 ze zm.). 
1918 roku ${ }^{15}$, w których jedynie wspomniano o obowiązku urzędników złożenia przysięgi na wierność Republice Polskiej oraz o mianowaniu wyższych urzędników przez Naczelnika czy w związku z utworzeniem Kancelarii Cywilnej Naczelnika $^{16}$. Dopiero w 1919 roku zaczynają być podejmowane najpierw dekrety ${ }^{17}$, a następnie - przez wybrany już sejm - ustawy o organizacji administracji państwowej $^{18}$, a na ich podstawie rozporządzenia wykonawcze ${ }^{19}$, w których regulowane są częściowo stosunki zatrudnienia urzędników i pozostałych pracowników jej urzędów. Proces ten był kontynuowany w następnych latach równolegle $\mathrm{z}$ ostatecznym wyznaczaniem granic państwa ${ }^{20}$.

Cechą wspólną tych regulacji było odwoływanie się do tymczasowych przepisów służbowych z czasów Rady Regencyjnej, a zwłaszcza ich tabel płacowych, które stanowiły odniesienia dla posługiwania się stopniami służbowymi i kategoriami płacowymi, do czasu zastąpienia ich regulacją z $1920 \mathrm{roku}^{21}$. Na podkreśle-

15 Dekret z dnia 29 listopada 1918 r. o najwyższej władzy reprezentacyjnej Republiki Polskiej (Dz.U. Nr 17, poz. 41), na podstawie jego art. 6 wydane zostało dnia 22 listopada 1919 r. rozporządzenie Rady Ministrów w przedmiocie nowego tekstu roty przysięgi dla ministrów, urzędników i sędziów (Dz.U. Nr 89, poz. 486).

16 Dekret z dnia 11 grudnia 1918 r. w przedmiocie utworzenia Kancelarji Cywilnej Naczelnika Państwa (Dz.U. Nr 20, poz. 59) oraz Rozporządzenie Rady Ministrów z dnia 11 grudnia 1918 r. w przedmiocie tymczasowych etatów dla urzędników Kancelarji Cywilnej Naczelnika Państwa (Dz.U. Nr 20, poz. 60).

17 Por. Przepisy tymczasowe o wynagrodzeniu urzędników Inspekcji pracy z dnia 3 stycznia 1919 r. (Dz.U. Nr 5, poz. 91); art. 2, 4, 5, 7, 20, 23 Dekretu z dnia 16 stycznia 1919 r. w przedmiocie organizacji urzędów ochrony lasów (Dz.U. Nr 8, poz. 117 ze zm.); art. 2-5 Dekretu z dnia 7 lutego 1910 r. o Najwyższej Izbie Kontroli Państwa (Dz.U. Nr 14, poz. 183).

18 Por. art. 5-7 Ustawy z dnia 31 lipca 1919 r. o tymczasowej organizacji władz i urzędów skarbowych (Dz.U. Nr 65, poz. 391); art. 10-12 i art. 15 Ustawy z dnia 1 sierpnia 1919 r. o tymczasowej organizacji zarządu b. dzielnicy pruskiej (Dz.U. Nr 64, poz. 385) wraz z § 6-8, 10-15, 18, 36-41, 51 Rozporządzenia Ministra b. dzielnicy pruskiej z dnia 23 września 1921 r. w przedmiocie organizacji władz i urzędów skarbowych w b. dzielnicy pruskiej (Dz.U. Nr 101, poz. 724 ze zm.); art. 2-4 Ustawy tymczasowej z dnia 2 sierpnia 1919 r. o organizacji władz administracyjnych II instancji (Dz.U. Nr 65, poz. 395).

19 Por. art. 4-6 Rozporządzenia Rady Ministrów z dnia 8 kwietnia 1919 r. w przedmiocie utworzenia Instytutu Torfowego (Dz.U. Nr 34, poz. 271); art. 3-9 Rozporządzenia Rady Ministrów z dnia 17 kwietnia 1919 r. w przedmiocie utworzenia Państwowego Urzędu Meljoracji Rolnych (Dz.U. Nr 34, poz. 272); art. 3, 5 i 6 Rozporządzenia Rady Ministrów z dnia 28 kwietnia 1919 r. w przedmiocie organizacji państwowego instytutu meteorologicznego (Dz.U. Nr 39, poz. 290); art. 2, 5-14 Rozporządzenia Rady Ministrów z dnia 11 maja 1919 r. w przedmiocie organizacji Zarządów Dóbr Państwowych (Dz.U. Nr 41, poz. 301); art. 1-5 Rozporządzenia z dnia 28 lipca 1919 r. w przedmiocie organizacji Państwowych Zakładów badania żywności i przedmiotów użytku (Dz.U. Nr 71, poz. 420).

20 Zob. § 2 Rozporządzenia Rady Ministrów z dnia 18 listopada 1920 r. w przedmiocie utworzenia władz administracyjnych drugiej instancji na obszarze ziem, objętych umową o preliminaryjnym pokoju i rozejmie, podpisaną w Rydze, dn. 12 października 1920 r. (Dz.U. Nr 115, poz. 760).

21 Ustawa z dnia 13 lipca 1920 r. o uposażeniu urzędników i niższych funkcjonariuszów państwowych (Dz.U. Nr 65, poz. 429 ze zm.) wraz z Rozporządzeniem Rady Ministrów z dnia 4 października 1920 r. o dodatkach reprezentacyjnych i dodatkach za kierownictwo dla urzęd-

Prawo 327, 2019

(C) for this edition by CNS 
nie zasługuje też utrzymywany publicznoprawny charakter stosunku służbowego urzędników i pozostałych funkcjonariuszy publicznych. Jak wspomniano, regulacje pojawiały się w miarę rozwoju stopnia zorganizowania państwa ${ }^{22}$, ale też stanu posiadania, gdy idzie o obszar nowego państwa, stąd regulacje dotyczące poszczególnych regionów włączanych w granice państwowe w miarę stabilizowania się sytuacji międzynarodowej, ale też działań militarnych na granicy wschodniej. Szczególnym tego przykładem są regulacje z okresu wojny polsko-bolszewickiej, gdy część urzędników i pracowników administracji podlegała powołaniu do służby wojskowej ${ }^{23}$, gdy warunki wojenne istotnie wpływały na sytuację ekonomiczną funkcjonariuszy ${ }^{24}$, ale też gdy odpowiedzialność urzędników przyjmowała charakter szczególny na tle znanych wcześniej (i później) katalogów kar za delikty służbowe ${ }^{25}$, choć zarazem zauważyć należy regulacje wspomagające urzędników powracających ze służby wojskowej ${ }^{26}$.

ników państwowych (Dz.U. Nr 97, poz. 638 ze zm.) oraz rozporządzenia tymczasowe: Prezydenta Ministrów i Ministra Skarbu z dnia 5 sierpnia 1920 r. w sprawie przyznania państwowym funkcjonariuszom niższym płac zasadniczych poszczególnych stopni, przewidzianych w artykule 14 Ustawy o uposażeniu urzędników i niższych funkcjonariuszów państwowych z dnia 13 lipca $1920 \mathrm{r}$. Dz.U.Rz.P. № 65 poz. 429 (Dz.U. Nr 77, poz. 520); Prezydenta Ministrów, Ministra Skarbu i Ministra b. dzielnicy pruskiej z dnia 30 września 1920 r. w sprawie przyznania państwowym funkcjonariuszom niższym płac zasadniczych poszczególnych stopni, przewidzianych w artykule 14 Ustawy o uposażeniu urzędników i niższych funkcjonariuszów państwowych z dnia 13 lipca $1920 \mathrm{r}$. Dz.U.Rz.P. № 65 poz. 429 (Dz.U. Nr 95, poz. 626 ze zm.). Wypada też wspomnieć o Ustawie emerytalnej funkcjonariuszów państwowych z dnia 28 lipca 1921 r. (Dz.U. Nr 70, poz. 466 ze zm.).

22 Dobrym przykładem jest Ustawa z dnia 6 lipca 1920 r. o organizacji urzędów ziemskich (Dz.U. Nr 70, poz. 461), która w art. 1 akcentuje utrwalanie nowego ustroju rolnego w państwie i dla tego celu ustala ustrój oraz status prawny urzędników zatrudnionych w Głównym Urzędzie Ziemskim (art. 5-7), okręgowych (art. 14) i powiatowych (art. 22) urzędach ziemskich.

23 Ustawa z dnia 11 lipca 1919 r. normującą stosunki służbowe funkcjonariuszów państwowych podczas pełnienia służby wojskowej (Dz.U. Nr 59, poz. 357); Rozporządzenie Rady Obrony Państwa z dnia 30 lipca 1920 r. w przedmiocie zastępstwa na urzędach, opróżnionych z powodu wstąpienia odnośnych urzędników do wojska (Dz.U. Nr 71, poz. 480).

${ }^{24}$ Ustawa z dnia 27 stycznia 1920 r. w sprawie przyznania nadzwyczajnego dodatku drożyźnianego urzędnikom i funkcjonariuszom państwowym, egzekutorom podatkowym, funkcjonariuszom kolei państwowych, nauczycielom szkół powszechnych, zawodowych, państwowych szkół średnich, seminariów nauczycielskich i preparand oraz szkół wyższych (Dz.U. Nr 7, poz. 47 ze zm.).

25 Ustawa z dnia 30 stycznia 1920 r. w przedmiocie odpowiedzialności urzędników za przestępstwo popełnione z chęci zysku (Dz.U. Nr 11, poz. 60) wraz z Rozporządzeniem Rady Obrony Państwa z dnia 6 sierpnia 1920 r. w przedmiocie poddania przestępstw, popełnionych przez urzędników z chęci zysku — orzecznictwu sądów doraźnych (Dz.U. Nr 75, poz. 501) oraz Ustawą z dnia 18 marca 1921 r. o zwalczaniu przestępstw z chęci zysku, popełnionych przez urzędników (Dz.U. Nr 30, poz. 177) — wszystkie te regulacje przewidywały karę śmierci przez rozstrzelanie.

26 Rozporządzenie Ministra Spraw Wojskowych, Ministra Pracy i Opieki Społecznej, Ministra Skarbu oraz Ministra b. dzielnicy pruskiej z dnia 22 listopada 1921 r. o obsadzaniu wolnych miejsc pracy w zakładach samorządowych oraz prywatnych, subwencjonowanych i koncesjonowanych przez Państwo (Dz.U. Nr 96, poz. 707 ze zm.).

Prawo 327, 2019

(C) for this edition by CNS 
W 1919 roku podejmowane są akty nowego prawa samorządowego, w których występują regulacje odnoszące się do zatrudnienia pracowników samorządo$w_{y c h}{ }^{27}$. Ten stan tymczasowości a zarazem fragmentaryczności regulacji odnoszonych osobno do gmin i powiatów, a także obu sejmików wojewódzkich, a przede wszystkim do każdej z dzielnic porozbiorowych, utrzymuje się w zasadzie do przyjęcia tzw. ustawy scaleniowej z 1933 roku. Udowadnia to, że w odróżnieniu od administracji rządowej, sprawy ustroju samorządowego wymagały znacznie więcej czasu, ale też być może nie były tak priorytetowe jak uregulowanie ustroju władzy centralnej. Miało to jednak negatywny wpływ na możliwość powstania samorządowego prawa urzędniczego, bowiem - o czym będzie jeszcze mowa nigdy nie doszło w okresie międzywojennym do ustawowego uregulowania statusu prawnego pracowników samorządowych, a tym samym do jego ujednolicenia. Pozostał on wyłącznie na poziomie regulacji statutowych poszczególnych jednostek samorządu terytorialnego ${ }^{28}$.

\section{Państwowa służba cywilna i pozostałe regulacje prawa urzędniczego do roku 1939}

Jak postrzegał ten okres Immanuel Iserzon, ,rodzima biurokracja wykształciła się na wzorach austriackich i pruskich (z przewagą austriackiego)", toteż nie powinno dziwić, że w toku prac nad założeniami jednolitego uregulowania podstaw państwowej służby cywilnej wzorce austriackie zdominowały też ich ostateczny efekt ujęty w pierwszej pełnej i nietymczasowej ustawie polskiego prawa urzędniczego z 1922 roku $^{29}$. Ustawa przyjmowała ugruntowany w ówczesnej Europie

27 Por. art. 21 pkt 7, 8 i 16, art. 40-45, art. 47 pkt 7, art. 48-50, art. 53-56, art. 67 Dekretu z dnia 4 lutego 1919 r. o samorządzie miejskim (Dz.U. Nr 13, poz. 140 ze zm.); art. 17 pkt 5 i 8 , art. 33-38, 40-44 Dekretu z dnia 4 lutego 1919 r. o tymczasowej ordynacji powiatowej dla obszarów Polski byłego zaboru rosyjskiego (Dz.U. Nr 13, poz. 141 ze zm.); rozporządzenia Rady Ministrów: z dnia 28 sierpnia 1919 r.: o tymczasowej organizacji powiatowych władz administracyjnych I instancji na obszarze b. zaboru rosyjskiego (Dz.U. Nr 72, poz. 426) i w przedmiocie uposażenia pisarzy gminnych i ich pomocników na obszarze byłego zaboru rosyjskiego (Dz.U. Nr 72, poz. 427).

$28 \mathrm{Na}$ ten temat zob. J. Korczak, Status prawny pracowników samorządowych w II i III RP, [w:] 20 lat samorzadu terytorialnego w II i III Rzeczypospolitej. I Wydziałowa Konferencja Kót Naukowych Wydziału Prawa, Administracji i Ekonomii Uniwersytetu Wrocławskiego, red. J. Korczak, Wrocław 2010, s. 379-404.

${ }^{29}$ Ustawa z dnia 17 lutego 1922 r. o państwowej służbie cywilnej (Dz.U. Nr 21, poz. 164 ze zm.). Zob. E. Iserzon, Prawo administracyjne, Wydawnictwo Prawnicze, Warszawa 1968, s. 182. Proces kilkuletnich prac nad ustawą został zanalizowany także w: W. Jaśkiewicz, Studia nad sytuacja prawna pracowników państwowych, t. 1, Poznań 1961, s. 90-98, przywołując m.in. ówczesny pogląd o potrzebie nadania stanowi urzędniczemu pragmatyki określającej jego kartę praw i obowiązków niezbędnych dla funkcjonowania państwa. 
publicznoprawny charakter stosunku służbowego łączącego pracownika państwowego z państwem (art. 1) nawiązywanego przez mianowanie w piśmie nominacyjnym, w którym wymieniano urząd, tytuł urzędowy i grupę uposażenia (art. 4) bez względu na to, czy mianowanie było na stałe, czy też do odwołania (art. 5).

Do absolutnych wyjątków należało zatrudnianie w administracji tzw. pracowników kontraktowych, o których marginalnie wspominał art. 14, określając ją jako „państwowa służba kontraktowa”, jako miejsca zatrudnienia, z którego przechodzić mógł przyszły urzędnik do służby cywilnej. Zatrudnienie pracowników kontraktowych miało miejsce z kilku powodów, zasadniczo w przypadkach gdy nawiązanie stosunków służbowych nie miało podstawy prawnej lub też gdy wynikało to z rodzaju lub czasu trwania służby ${ }^{30}$. Kategoria ta była zróżnicowana, obejmowała bowiem stanowiska de facto urzędnicze (czego przykładem byli tzw. dietariusze - nieetatowi pracownicy dziennie płatni, których przyjmowano dla wykonania zadań okresowo występujących z powodu niemożności wykonania ich przy wykorzystaniu zatrudnionej kadry urzędniczej, jak np. organizacja poboru do wojska lub wystąpienie nadzwyczajnych obciążeń z innej przyczyny), ale też stanowiska technicznych pomocników funkcjonariuszy, zwanych personelem kancelaryjnym i manipulacyjnym ${ }^{31}$, ich zatrudnienie następowało na podstawie przepisów dotyczących umów o pracę pracowników umysłowych i robotników ${ }^{32}$.

Zwraca uwagę zakres podmiotowy pragmatyki z 1922 roku, albowiem obejmowała ona nie tylko ogół funkcjonariuszy zatrudnionych na stanowiskach urzędniczych, ale też ministrów i innych konstytucyjnie odpowiedzialnych kierowników władz naczelnych i centralnych w zakresie, $w$ jakim nie podlegali przepisom odrębnym, a nawet Prezydenta RP po ustąpieniu z urzędu w zakresie co prawda jedynie stawki wynagrodzenia, chyba że decydował się wówczas na wstąpienie do korpusu ${ }^{33}$. W porównaniu z obecnym stanem prawnym, w którym nie tylko Prezydent RP, członkowie Rady Ministrów, ale nawet wojewodowie nie podlegają

30 J. Kościołek, Państwowa służba cywilna. Jednolity tekst pragmatyki i komentarz, Łódź 1947, s. 11-12 przywołuje okólnik Prezesa Rady Ministrów Nr 49 z dnia 31 grudnia 1935 r., w myśl którego „kandydaci na stanowiska, z którymi związane jest wykonywanie zadań specjalnych, wymagających przede wszystkim szczególnego zaufania kierowników władz naczelnych, mogli być przyjmowani do służby państwowej na stanowiska wymagające w zasadzie publiczno-prawnego stosunku jedynie tylko czasowo, w drodze zawarcia umowy służbowej”. Negatywnie praktykę tę ocenia M. Jaroszyński, Problemy personalne $w$ administracji publicznej. Tom X Materiatów Komisji do usprawnienia Administracji Publicznej przy Prezesie Rady Ministrów, Warszawa 1933, wskazując m.in. wykorzystywanie jej dla obchodzenia przepisów pragmatyki z 1922 r. w zakresie obowiązku odbywania służby przygotowawczej, wymogów kwalifikacyjnych na poszczególne stanowiska itp.

31 J. Kościołek, op. cit., s. 14-15.

32 Rozporządzenia Prezydenta RP z dnia 16 marca 1928 r.: o umowie o pracę pracowników umysłowych (Dz.U. Nr 35, poz. 323 ze zm.) i o umowie o pracę robotników (Dz.U. Nr 35, poz. 324 ze zm.).

33 Zob. J.S. Langrod, Stużba państwowa [w:] K.W. Kumaniecki, J.S. Langrod, S. Wachholz, Zarys ustroju, postępowania i prawa administracyjnego w Polsce, Kraków-Warszawa 1939, s. 47-49. 
regulacjom prawa urzędniczego w żadnym zakresie, a ich statusy prawne są często trudne do jednoznacznego ustalenia, fenomen regulacyjny pragmatyki z 1922 roku jest nie do przecenienia.

Korpus służby cywilnej był wewnętrznie zróżnicowany na dwie grupy: urzędników i niższych funkcjonariuszy państwowych (art. 3). Urzędnicy zgodnie $\mathrm{z}$ art. 11 byli podzieleni na 3 kategorie ze względu na poziom wymaganego do zatrudnienia wykształcenia (I - wykształcenie wyższe, II - wykształcenie średnie ogólnokształcące lub zawodowe, III — szkoła powszechna lub najniższe klasy szkoły średniej), co miało powiązanie z obowiązującymi do 1934 roku $^{34}$ dwunastu stopniami służbowymi na tej zasadzie, że kategoria I obejmowała stopnie I-VIII, kategoria II obejmowała IX i X stopień, a kategoria III stopnie XI i XII (art. 17) z zasadą starszeństwa służbowego urzędników ze względu na posiadany stopień (art. 18). Ustawa w art. 41 gwarantowała prawo awansu na wyższy stopień po spełnieniu określonych wymogów (liczba lat służby, zaufanie przełożonych poparte wynikami oceny kwalifikacyjnej z art. 20, posiadanie specjalnych kwalifikacji wymaganych na wyższym stanowisku). Podział na stopnie przenosił się na uprawnienia w zakresie mianowania, które w zakresie pierwszych czterech stopni zastrzegało mianowanie do wyłącznej właściwości Prezydenta RP, w zakresie pozostałych do właściwości władz naczelnych w zależności od podległego im urzędu, z zastrzeżeniem uzyskania uprzedniej zgody Prezesa Rady Ministrów do mianowania na stopień VII i VIII oraz możliwością upoważnienia do mianowania w obrębie stopni I-V kierownikom władz podległych władzom naczelnym (art. 17 ust. 5 i 6). Funkcjonariusze niżsi nie byli dzieleni wewnętrznie na jakiekolwiek kategorie, a wymogi kwalifikacyjne ograniczono jedynie do umiejętności czytania i pisania po polsku i spełnienia ewentualnych wymagań praktycznych ${ }^{35}$.

Na status prawny funkcjonariuszy państwowych okresu po wejściu w życie pragmatyki z 1922 roku składały się też ich szczególne obowiązki (art. 21-32) ${ }^{36}$

34 Na podstawie art. 1 pkt 1 Rozporządzenia Prezydenta RP z dnia 28 października 1934 r. w sprawie zmiany ustawy z dnia 17 lutego 1922 r. o państwowej służbie cywilnej (Dz.U. Nr 86, poz. 661) stopnie zastąpiono grupami uposażenia (również dwunastoma) i zniesiono starszeństwo służbowe $\mathrm{z}$ art. 18.

35 Przykładowo rozporządzenie Ministra Robót Publicznych z dnia 9 maja 1931 r. o ustaleniu specjalnych wymagań od kandydatów na niższych funkcjonariuszów państwowych w dziale drogowym i na niektóre stanowiska w dziale wodnym służby na lądzie (Dz.U. Nr 64, poz. 528) wymagało od kandydata ukończenia co najmniej 21 lat, odbycia służby wojskowej i ukończenia co najmniej 4 klas szkoły powszechnej lub zawodowej, a także odbycia specjalistycznych kursów (§ 1), od kandydatów na stanowisko kierowców maszyn drogowych i nadzorców dróg i urządzeń wodnych odpowiednich uprawnień do ich prowadzenia i innych uprawnień o charakterze technicznym (\$ 2 i 3$)$.

36 J.S. Langrod wyróżniał ich dwanaście, dzieląc je ostatecznie na 3 grupy: 1) gorliwego, uczciwego, sumiennego, bezstronnego i zgodnego z przepisami pełnienia urzędu; 2) wierności, posłuszeństwa i zachowania tajemnicy urzędowej; 3) przestrzegania godności stanu i odpowiedniego prowadzenia się - idem, op. cit., s. 749-750). 
i odpowiadające im szczególne prawa (art. 33-51) 37, odpowiedzialność dyscyplinarna w zakresie występków, za popełnienie których komisja dyscyplinarna mogła nakładać kary dyscyplinarne, oraz wykroczeń służbowych, za których popełnienie przełożony mógł nakładać kary porządkowe (art. 66-88), a także szczególna ochrona stosunku służbowego (tytuł II rozdział IV). Przepisy te stosowano odpowiednio do funkcjonariuszy niższych.

Pragmatyka z 1922 roku do wybuchu II wojny światowej była zmieniana aż czternastokrotnie ${ }^{38}$, co dowodzi, że jej uchwalenie nie było równoznaczne z przyjęciem jednolitego modelu służby cywilnej, a w dodatku sama regulacja była narzędziem, przy pomocy którego władza naczelna realizowała swoje cele polityczne. Można tak wnioskować, analizując treść i skutki zmian w układzie chronologicznym - do przewrotu majowego z 1926 roku miało miejsce 5 zmian, których charakter był typowy dla zabiegów projakościowych (uzupełnianie luk lub usuwanie oczywistych błędów legislacyjnych). Po przewrocie zaś następne 9 zmian służyło raczej coraz większemu uzależnianiu członków korpusu od władz politycznych i ograniczeniu ich pierwotnych uprawnieńn ${ }^{39}$. Niemniej jednak należy docenić znaczenie tej regulacji jako pierwszej i tak obszernej w historii polskiego prawa urzędniczego, która ustanowiła jego fundamentalne instytucje oraz zasady: korpusowego charakteru zatrudnienia, zależności między formą nawiązania stosunku zatrudnienia (służbowego lub pracy) a jego treścią i wynikającym z nich statusem funkcjonariusza publicznego, stabilizację zatrudnienia, zasadę oddzielenia stanowisk politycznych od urzędniczych, zasadę fachowości i profesjonalizmu,

37 J.S. Langrod dzielił je na: ekonomiczne (uposażenie służbowe, dodatki służbowe, zabezpieczenia przeciwegzekucyjne, ulgi na przejazdy państwowymi środkami komunikacyjnymi, mieszkania służbowe, umundurowanie, zaopatrzenie wdów i sierot po urzędniku); socjalne (coroczny płatny urlop wypoczynkowy, opieka lekarska, prawo do odpoczynku od pracy w dni świąteczne); honorowe (prawo do tytułu, noszenie munduru i odznak służbowych, szczególna ochrona prawna w zakresie wykonywania czynności służbowych) — ibidem, s. 750-751.

38 Pomijam zmiany dokonywane przez Prezydenta RP na emigracji: Dekret z dnia 20 października 1939 r. o udzieleniu bezpłatnego urlopu urzędnikom i funkcjonariuszom państwowym, sędziom i prokuratorom oraz urzędnikom i pracownikom samorządu terytorialnego i gospodarczego, przedsiębiorstw państwowych i samorządowych i wszelkich instytucyj publicznych, którzy w związku z wojną opuścili obszar państwa (Dz.U. Nr 100, poz. 1001) oraz dekret z dnia 12 lipca 1940 r. o tymczasowej zmianie przepisów ustawy o państwowej służbie cywilnej (Dz.U. Nr 11, poz. 29), z uwagi na ich incydentalny charakter oraz bardzo ograniczone oddziaływania, a wreszcie i to, że po zakończeniu II wojny światowej nie były one brane pod uwagę na terytorium państwa.

39 Dobrym przykładem może być art. 41, który pierwotnie uzależniał awans do wyższych stopni od uzdolnienia, użyteczności i stopnia zaufania oraz posiadania szczególnych kwalifikacji do danego stanowiska, by po zmianie z 1932 r. uzależnić go od uznania władzy przełożonej. Jak pisał E. Iserzon ,po przewrocie w 1926 r. ster rządów objęli ludzie »reżimowi« [...]. Wyższa służba państwowa stała się dostępna tylko dla "pretorianów reżimu«" (E. Iserzon, op. cit., s. 162). Zdaniem W. Jaśkiewicza „koncepcja ta uwzględniała warunki ustrojowe [...] oraz potrzeby centralizmu biurokratycznego, który cechował administrację państwową" - W. Jaśkiewicz, Sytuacja prawna pracowników administracji państwowej, [w:] Pracownicy administracji w PRL, red. J. Łętowski, Wrocław 1984, s. 45. 
otwartości w dostępie do służby publicznej i inne. Następujące po II wojnie światowej przekształcenia ustrojowe państwa i w obszarze regulacji prawa urzędniczego pozostają zawsze w jakiejś relacji do rozwiązań z 1922 roku.

\section{Pierwsze regulacje powojenne}

Wyzwalanie ziem polskich spod okupacji niemieckiej następowało co prawda już od końca 1943 roku, ale dopiero latem 1944 wojska sowieckie przekroczyły przyszłą wschodnią granicę powojennego państwa i tym samym od tego momentu — z symboliczną datą 22 lipca 1944 roku, kiedy opublikowano pierwszy oficjalny dokument nowej władzy państwowej — datuje się polityczny byt państwa, które początkowo używało przedwojennej nazwy, aby zacząć stopniowo przechodzić na nazwę z przymiotnikiem ,ludowe”, co ostatecznie nastąpiło w Konstytucji Polskiej Rzeczpospolitej Ludowej z 22 lipca 1952 roku ${ }^{40}$. Mimo politycznej odmienności i ambicji, aby nowe państwo zdecydowanie odcięło się od sanacyjnej Polski przedwrześniowej, ówczesne władze, czyli Krajowa Rada Narodowa uzurpująca sobie funkcje ustawodawcze (co wyrażało się w formie ustawy, jaką się posługiwała) przynależne parlamentowi i Polski Komitet Wyzwolenia Narodowego uzurpujący sobie funkcje prawodawstwa administracyjnego (co wyrażało się w formie dekretów, jaką się posługiwał) przynależne rządowi ${ }^{41}$, musiały pogodzić się z trudnymi realiami procesu stworzenia nowego prawa od podstaw i poprzestały na modyfikacjach prawa powstałego w okresie znienawidzonej i krytykowanej sanacyjnej Polski.

Z tych powodów w obszarze prawa urzędniczego przez wiele lat nie powstanie nowa i samodzielna regulacja prawna, a władze tzw. ludowego państwa ograniczą się jedynie do zmian w prawie urzędniczym powstałym przed II wojną światową. Jednak skala i rodzaj tych zmian są niebagatelne i właściwie dorównują autonomicznym aktom legislacyjnym, jako że za ich pomocą dokonywano przewartościowania samej idei prawa urzędniczego i jego charakteru. W ich następstwie Polska po II wojnie światowej nie wróciła już nigdy do modelu prawa urzędniczego najbardziej rozpowszechnionego w Europie, czyli modelu kariery służbowej traktującego prawo urzędnicze jako prawo publiczne i stosującego korpusowy system organizacji kadr administracyjnych. Z oczywistych powodów nie przyjęła

40 Konstytucja Polskiej Rzeczypospolitej Ludowej uchwalona przez Sejm Ustawodawczy w dniu 22 lipca 1952 r. (Dz.U. z 1976 r. Nr 7, poz. 36 ze zm.).

41 Ustawa z dnia 21 lipca 1944 r. o utworzeniu Polskiego Komitetu Wyzwolenia Narodowego (Dz.U. Nr 1, poz. 1) oraz Ustawa z dnia 15 sierpnia 1944 r. o tymczasowym trybie wydawania dekretów z mocą ustawy (Dz.U. Nr 1, poz. 3). Od 1 stycznia 1945 został on zastąpiony Rządem Tymczasowym na mocy Ustawy z dnia 31 grudnia 1944 r. o powołaniu Rządu Tymczasowego Rzeczypospolitej Polskiej (Dz.U. Nr 19, poz. 99). 
zarazem anglosaskiego modelu zatrudnienia pozycyjnego, ale wykształciła własny model pośredni. Skutkiem tego jest traktowanie w następnych latach — także współcześnie - prawa urzędniczego jako części prawa pracy, a nie jako prawa publicznego.

W zmianach tych można wyróżnić kilka nurtów. Pierwszy polegał na tym, że co prawda pozostawiano w mocy przepisy ustawy o państwowej służbie cywilnej z 1922 roku, ale wyłączano z jej zakresu podmiotowego poszczególne grupy dawnych funkcjonariuszy państwowej służby cywilnej, co powodowało, że w końcowym okresie jej obowiązywania (lata 1968-1974) dotyczyła ona jedynie osób zatrudnionych $\mathrm{w}$ centralnych organach administracji państwowej ${ }^{42}$. Drugi nurt to stopniowe zacieranie różnic między kategoriami urzędników i niższych funkcjonariuszy państwowych, czego przykładem mogą być przepisy wspomnianego dekretu z 1944 roku zrównujące pracowników kontraktowych zatrudnionych po dniu 22 lipca 1944 roku ze stałymi funkcjonariuszami powracającymi do służby od tego dnia, a którzy byli w niej zatrudnieni przed 1 września 1939 roku, i to bez obowiązku zdawania egzaminów urzędniczych, jakie były wcześniej wymagane dla objęcia stanowiska ${ }^{43}$. Wreszcie ostatecznie zrezygnowano z terminologii pierwotnej skreślając w 1948 roku art. 3 ustawy z 1922 roku, co spowodowało, że termin ,urzędnik” przestał być terminem normatywnym na następne 34 lata i zastępując termin ,funkcjonariusz państwowy” terminem ,pracownik państwowy”44. Co prawda pozornie zostawiano instytucję mianowania jako formę nawiązywania stosunku służbowego, ale w praktyce dla stanowisk niższych mianowanie zastępowano umową o pracę ${ }^{45}$.

\section{Prawo urzędnicze do 1974 roku}

Po okresie zmian dokonywanych dekretami, zwłaszcza po uchwaleniu Konstytucji PRL, następowało jedynie wprowadzanie nowych regulacji prawnych

42 Przykładem jest Dekret PKWN z dnia 27 grudnia 1944 r. o tymczasowym unormowaniu stosunku służbowego i zaszeregowania funkcjonariuszów państwowych (Dz.U. Nr 16, poz. 89), który w art. 1 ust. 3 wyłączył spod zakresu podmiotowego ustawy kilka kategorii osób zatrudnionych w różnych instytucjach państwowych.

43 Ibidem, art. 5 i 8.

44 Por. art. 1 Dekretu z dnia 25 października 1948 r. o zmianie ustawy z dnia 17 lutego 1922 r. o państwowej służbie cywilnej (Dz.U. Nr 50, poz. 381 ze zm.).

45 Zalecał tę praktykę okólnik nr 1 Prezesa Rady Ministrów z dnia 31 stycznia 1949 r. (Dz.Urz. MAP Nr 12, poz. 57). W następnych latach przedstawiciele doktryny coraz bardziej krytycznie odnosili się do podziału pracowników administracji na mianowanych i umownych, dowodząc jego sprzeczności z duchem ustroju socjalistycznego, np. M. Święcicki, Przedmiot prawa pracy, [w:] Podstawowe problemy prawa pracy, red. Z. Salwa, W. Szubert, M. Święcicki, Warszawa 1957, s. 12; W. Jaśkiewicz, Stosunek stużbowy, a stosunek pracy, „Ruch Prawniczy i Ekonomiczny” 1960 , nr 2, s. 36. 
rangi ustawowej dla poszczególnych grup pracowników państwowych. Największa taka regulacja pod względem liczby pracowników nią objętych miała miejsce w 1968 roku i dotyczyła pracowników rad narodowych ${ }^{46}$.

Należy pamiętać, że w 1950 roku doszło do ostatecznej likwidacji samorządu terytorialnego i objęcia wszystkich jednostek zasadniczego podziału państwa systemem rad narodowych ${ }^{47}$, tym samym dotychczasowi pracownicy samorządowi zostali na mocy art. 39 ustawy przeniesieni do służby w odpowiednich wydziałach prezydiów rad narodowych w charakterze pracowników państwowych ${ }^{48}$. Z uwagi na koncepcję jednolitości ustrojowej w terenie poza radami narodowymi i ich prezydiami nie tworzono w sferze administracji ogólnej żadnych innych organów, co wskazuje, że była to administracja skupiająca poza administracją centralną oraz nielicznymi organami administracji specjalnej większość ówczesnych pracowników administracji państwowej. W następnych latach pracownicy tych prezydiów byli zatrudniani na podstawie przepisów wykonawczych wydanych na podstawie art. 24 ustawy tj. uchwał Rady Ministrów, które w formie instrukcji regulowały odrębnie zatrudnienie członków prezydium oraz pracowników zajmujących stanowiska kierownicze, a odrębnie pozostałe stanowiska ${ }^{49}$. Również wejście w życie ustawy o radach narodowych nie zmieniło istotnie statusu prawnego tych pracowników, bowiem jej art. $58 \mathrm{w}$ zakresie zatrudnienia członków prezydiów i pozostałych ich pracowników odsyłał do aktów wykonawczych ${ }^{50}$.

Toteż uchwalenie wspomnianej ustawy o pracownikach rad narodowych z 1968 roku podnosiło znacznie rangę regulacji ich statusu pracowniczego na wzór tradycyjnego prawa urzędniczego opartego na regulacji ustawowej. Ustawa wyraźnie podkreślała związek z jeszcze nieskodyfikowanym ustawodawstwem pracy (art. 2) i przewidywała dwie kategorie pracowników z uwagi na formę ich zatrudnienia: zatrudnionych na stanowiskach kierowniczych na podstawie powołania (art. 13 ust. 2) dokonywanego na podstawie uchwały prezydium rady

46 Ustawa z dnia 15 lipca 1968 r. o pracownikach rad narodowych (Dz.U. Nr 25, poz. 68).

47 Ustawa z dna 20 marca 1950 r. o terenowych organach jednolitej władzy państwowej (Dz.U. $\mathrm{Nr} 14$, poz. 130 ze zm.).

48 Szczegółowe zasady tego przeniesienia regulowała Uchwała Rady Ministrów z dnia 11 sierpnia $1950 \mathrm{r}$. Instrukcja nr 12 w sprawie unormowania stosunku służbowego pracowników samorządowych, którzy przeszli do służby w wydziałach prezydiów rad narodowych (M.P. Nr A-97, poz. 1221 ze zm.).

49 Uchwała Rady Ministrów z dnia 17 kwietnia 1950 r. Instrukcja nr 2 w sprawie składu, podziału pracy i trybu działania prezydiów rad narodowych (M.P. Nr A-57, poz. 654 ze zm.), została ona w znacznym stopniu zastąpioną Uchwałą nr 121 Rady Ministrów z dnia 5 marca 1956 r. w sprawie obsadzania i zmian na stanowiskach pracowniczych w prezydiach rad narodowych (M.P. Nr 25, poz. 357).

50 Ustawa z dnia 25 stycznia 1958 r. o radach narodowych (Dz.U. Nr 5, poz. 16 ze zm.) i wydane na podstawie art. 58 Rozporządzenie Rady Ministrów z dnia 19 lipca 1963 r. w sprawie obsadzania i zmian na stanowiskach pracowniczych prezydiów rad narodowych oraz niektórych stanowiskach w przedsiębiorstwach, zakładach i instytucjach podporządkowanych radom narodowym (Dz.U. Nr 35, poz. 203). 
narodowej (art. 15) oraz pracowników zatrudnianych na pozostałych stanowiskach w wydziałach i innych organach tworzonych zamiast wydziałów (art. 1 ust. 2) na podstawie umowy o pracę (art. 13 ust. 1). Mimo to pozostawały w niej widoczne wpływy prawa urzędniczego lat poprzednich, choćby w postaci instytucji zawieszenia pracownika (art. 19 i 20), stabilizacji zatrudnienia przez ograniczenie dowolności rozwiązania jego stosunku pracy (art. 24), odpowiedzialności służbowej i dyscyplinarnej (art. 48-51) z komisjami dyscyplinarnymi w zakresie orzekania o odpowiedzialności dyscyplinarnej (art. 52-56). Jednocześnie zauważalny był też wpływ ideologii państwa socjalistycznego na zatrudnienia wyrażający się m.in. w katalogu wymagań kwalifikacyjnych z art. 11 ustawy, gdzie obok tak oczywistych wymagań, jak posiadanie obywatelstwa polskiego i pełni praw publicznych oraz zdolności do czynności prawnych podkreślano poziom ideowo-moralny kandydata dający rękojmię należytego wykonywania zadań pracownika rady narodowej, co zapewne rzutowało w praktyce na wyniki okresowej oceny pracy przeprowadzanej na podstawie art. $16^{51}$, a przecież jej negatywny wynik był przesłanką rozwiązania stosunku pracy w drodze wypowiedzenia z art. 24 ust. 1 pkt 2.

\section{Kodyfikacja prawa pracy i jej skutki dla prawa urzędniczego}

W czerwcu 1974 roku, po kilku latach prac nad projektami jako jedno z ostatnich państw socjalistycznych Polska dokonała kodyfikacji prawa pracy ${ }^{52}$, a jednocześnie zniosła wszelkie odrębne regulacje prawne dotyczące zatrudnienia w ówczesnej administracji państwowej ${ }^{53}$. W ich miejsce dziś już uchylony art. $298 \S 1$ Kodeksu pracy upoważniał Radę Ministrów do określenia w drodze rozporządzenia niektórych praw i obowiązków pracowników zatrudnionych w urzędach państwowych i innych działach służby państwowej, a także w zakładach służby zdrowia, jednostkach wojskowych i innych zakładach pracy, na stanowiskach związanych ze służbą zagraniczną lub obronnością kraju, a ponadto pracowników zatrudnionych za granicą w przedsiębiorstwach polskich. Zgodnie z $§ 2$ tego przepisu rozporządzenie mogło ustalać specjalne wymagania kwalifikacyjne w zakresie kwalifikacji osobistych i zawodowych, a także zasady i tryb przeno-

51 O politycznej kontroli sprawowanej przez ówczesną Polską Zjednoczoną Partię Robotniczą nad kierowniczymi kadrami jednostek aparatu państwowego: W. Jaśkiewicz, Pracownicy administracji, [w:] System Prawa Administracyjnego, red. J. Jendrośka, t. 2, Wrocław 1977, s. 381-384.

52 Ustawa z dnia 26 czerwca 1974 r. - Kodeks pracy (Dz.U. z 2018 r. poz. 917).

53 Na mocy art. 4 § 1 i pkt 20 Ustawy z dnia 26 czerwca 1974 r. — Przepisy wprowadzające Kodeks pracy (Dz.U. Nr 24, poz. 142) uchylono pragmatykę z 1922 r. (pkt 2) i ustawę z 1968 r. (pkt 20). 
szenia na inne stanowiska, zasady odpowiedzialności służbowej i zawieszania w czynnościach, ponadto mogło ustalać w sposób szczególny czas pracy i zasady wynagradzania za godziny nadliczbowe, wreszcie $\S 3$ art. 298 upoważniał Radę Ministrów do zastosowania aktu mianowania oraz aktu powołania do zatrudniania na wskazane w rozporządzeniu stanowiska.

Realizując tę delegację, Rada Ministrów wydała w grudniu 1974 roku rozporządzenie w sprawie praw i obowiązków pracowników urzędów państwowych ${ }^{54}$, w którym obok wymagań kwalifikacyjnych specjalistycznych z uwagi na charakter stanowisk (§ 3) oraz tak oczywistych, jak zdolność do czynności prawnych, posiadanie obywatelstwa polskiego i pełni praw publicznych wymagano od kandydata do zatrudnienia odpowiedniej postawy ideowo-moralnej oraz dawania rękojmi należytego wykonania zadań pracownika urzędu (§ 2). Rozporządzenie różnicowało pracowników urzędów ze względu na zajmowane stanowiska na dwie kategorie: zatrudnianych na podstawie aktu powołania (stanowiska kierownicze i samodzielne określone przez Prezesa Rady Ministrów — § 5) oraz zatrudnianych na podstawie umowy o pracę (pozostali pracownicy — §6). Z klasycznego katalogu instytucji prawa urzędniczego zachowano jedynie instytucję zawieszenia z mocy prawa z powodu tymczasowego aresztowania (§ 13) i zawieszenia fakultatywnego w razie dopuszczenia się deliktu służbowego (§ 14), rezygnując jednocześnie z jakichkolwiek rozwiązań ochronnych dla stabilności zatrudnienia, gwarancji awansu zawodowego czy nawet zwykłych ocen kwalifikacyjnych. Zrezygnowano zupełnie z odpowiedzialności służbowej na rzecz zwykłej odpowiedzialności pracowniczej z art. 108 Kodeksu pracy.

Doktryna reagowała na nowe rozwiązania różnie, ale nie było już zasadne utrzymywanie koncepcji mieszanego lub inaczej kompleksowego charakteru prawa służby publicznej ${ }^{55}$, co prowadziło do formułowania w świetle nowego stanu prawnego koncepcji „służbowego stosunku pracy” bez większego wnikania w istotę jego związku z formą nawiązania stosunku pracy ${ }^{56}$. Rozporządzenie oznaczało de facto ostateczny upadek polskiego prawa urzędniczego po okresie jego powolnego likwidowania rozpoczętego po 1944 roku i coraz większej dezintegracji środowiskowej uniemożliwiającej reprezentację interesów zawodowych

54 Rozporządzenie Rady Ministrów z dnia 20 grudnia 1974 r. w sprawie praw i obowiązków pracowników urzędów państwowych (Dz.U. Nr 49, poz. 300). Przypomnieć należy, iż wydano na tej samej podstawie 7 rozporządzeń wykonawczych dla pracowników służby zdrowia, kolei, poczty, lasów państwowych, służb dyplomatyczno-konsularnych i administracji celnej.

55 Zob. W. Jaśkiewicz, Studia nad sytuacją prawna pracowników państwowych, t. 2. Socjalistyczna stużba państwowa PRL — ZSRR, Poznań 1966, s. 245; autor formułował ją jako „zespół norm prawa administracyjnego i prawa pracy mających harmonijny udział w regulowaniu całości sytuacji pracowników państwowych”.

56 T. Zieliński, Problem stosunków stużbowych a kodyfikacja prawa pracy w PRL, „Państwo i Prawo" 1974, nr 6, s. 48 n. 
oraz w sprawach pracowniczych. W konsekwencji prowadziło to do upadku etosu urzędniczego i coraz niższej atrakcyjności zawodu urzędniczego w Polsce ${ }^{57}$.

\section{Restytucja prawa urzędniczego z 1982 roku}

Negatywne doświadczenia skutków stosowania rozporządzenia z 1974 roku oraz nowe warunki polityczne funkcjonowania państwa po sierpniu 1980 roku skłaniały do zmian w stanie ówczesnego prawa urzędniczego na rzecz przywrócenia należnej rangi regulacji pragmatyki urzędniczej i odrębności w regulacji statusu prawnego pracownikom administracji publicznej w stosunku do pracowników innych instytucji ${ }^{58}$. Uchwalona po ośmiu latach obowiązywania regulacji rozporządzeniowej pragmatyka urzędnicza z 1982 roku $^{59}$ nawiązywała w pewnym sensie do swojego pierwowzoru — pragmatyki z 1922 roku — po pierwsze, bardzo szerokim zakresem podmiotowym wyznaczonym treścią art. 1 i delegacjami rozporządzeniowymi z art. 2, 43-48, po drugie, przywróceniem terminu „urzędnik” (notabene po 38 latach od zastąpienia go terminem ,pracownik państwowy”) do języka normatywnego ${ }^{60}$, po trzecie, przywróceniem mianowania jako podstawowej formy prawnej zatrudnienia na stanowisku urzędniczym (art. 4) ze wszystkimi jego konsekwencjami.

Pragmatyka stwarzała szanse na przywrócenie właściwej rangi zawodu urzędnika państwowego nie tylko przez korzystne uprawnienia materialne mające podnieść atrakcyjność zatrudnienia w administracji (wprowadzenie: dodatków za wieloletnią pracę w art. 22, nagród jubileuszowych w art. 23, zakładowego funduszu nagród w art. 24, ulg w przejazdach środkami państwowej komunikacji w art. 25), ale też budowanie korporacyjnego charakteru grupy zawodowej przez położenie nacisku na wysoki poziom kwalifikacji zawodowych (np. wprowadzenie w art. 7 aplikacji administracyjnej jako wymogu do objęcia stanowiska czy ocen kwalifikacyjnych w art. 20), przywrócenie odpowiedzialności dyscyplinarnej

57 Por. J. Korczak, Kadry administracji publicznej wobec przeobrażeń we współczesnym prawie administracyjnym, [w:] Współczesne problemy administracji publicznej i prawa administracyjnego. Materiały z sesji naukowej na temat przeobrażeń we współczesnym prawie administracyjnym, Wrocław listopad 1997, red. A. Błaś, Wrocław-Poznań 1999, s. 43-56.

58 Zob. T. Kuczyński, J. Stelina, Geneza i kierunki rozwoju prawa stosunków stużbowych w Polsce, [w:] System Prawa Administracyjnego, red. R. Hauser, Z. Niewiadomski, A. Wróbel, t. 11. Stosunek stużbowy, Warszawa 2011, s. 85, autorzy przywołują poglądy doktryny tego okresu upatrujące związku pomiędzy kryzysami społecznymi a poziomem służb państwowych i hasło inspirujące uchwalenie pragmatyki „rząd i społeczeństwo chce mieć dobrych urzędników”.

59 Ustawa z dnia 26 września 1982 r. o pracownikach urzędów państwowych (Dz.U. z 2017 r. poz. 2142 ze zm.).

60 Por. J. Korczak, Pojęcie urzędnika państwowego w ustawie o pracownikach urzędów państwowych, „Organizacja — Metody — Technika” 1984, nr 10, s. 6-12. 
przed komisjami złożonymi z urzędników (rozdział 5), a nawet symboliczny gest jak ustanowienie odznaki honorowej (art. 31).

Pragmatyka przywracała stabilność zatrudnienia zwłaszcza z uwagi na treść art. 13 i 14 ustalających warunki rozwiązania lub stwierdzenia wygaśnięcia stosunku pracy. Przywracano też podstawowe instytucje prawa urzędniczego wpływające na dyspozycyjny charakter zatrudnienia w postaci rozwiązań dopuszczających zmienność treści stosunku pracy (art. 10), instytucję zawieszenia obligatoryjnego (art. 11) i fakultatywnego (art. 12). Istotny był powrót do częściowo publicznoprawnego charakteru mianowania urzędnika przez poddanie sporów dotyczących stosunku pracy kognicji sądów administracyjnych (art. 38 i 39).

Niestety, podobnie jak wielka poprzedniczka z 1922 roku, także i ta ustawa nie obowiązywała zbyt długo w swej pierwotnej postaci, ponadto - mimo nawet niezbyt istotnych zmian — poważnym mankamentem było nierespektowanie jej postanowień w praktyce, np. zaniechania mianowania, coraz mniej liczne pod względem udziału i coraz rzadziej organizowane aplikacje administracyjne. Największe zmiany nastąpiły w związku z transformacją ustrojową z przełomu lat 1989 i 1990, ale też w wyniku przyjęcia Konstytucji RP z 1997 roku i reformy sądownictwa administracyjnego z 2004 roku, które doprowadziły do tego, że mianowanie obecnie należy do wyjątków ${ }^{61}$, a spory zatrudnianych na podstawie umów o pracę urzędników państwowych podlegają właściwości sądów pracy (art. 39).

\section{Wpływ transformacji ustrojowej na prawo urzędnicze w Polsce}

Okoliczności polityczne końca lat 80. XX wieku doprowadziły dzięki obradom władz państwowych i środowisk opozycyjnych skupionych wokół Lecha Wałęsy wówczas legendy solidarnościowego zrywu z sierpnia 1980 roku, a w przyszłości pierwszego demokratycznie wybranego Prezydenta RP — w ramach tzw. okrągłego stołu do rozpoczęcia wieloletniego procesu transformacji ustrojowej ze scentralizowanego państwa socjalistycznego w demokratyczne państwo prawa. Jego filarami stała się decentralizacja władzy publicznej dzięki restytucji samorządu terytorialnego oraz budowa nowej koncepcji administracji rządowej, czym nawiązywano niejako do tradycji ustrojowych Polski międzywojennej. Dla tych celów

61 Na mocy Ustawy z dnia 2 grudnia 1994 r. o zmianie ustawy o pracownikach państwowych (Dz.U. Nr 136, poz. 704 ze zm.) uchylono art. 4-6, wykreślając mianowanie z katalogu form nawiązania stosunku pracy urzędników, rozszerzono instytucje zmiany stosunku pracy, osłabiono przepisy stabilizujące zatrudnienie itd. Mianowanie ma zastosowanie np. na podstawie Rozporządzenia Ministra Obrony Narodowej z dnia 4 sierpnia 2015 r. w sprawie jednostek wojskowych oraz stanowisk, na których stosunek pracy z pracownikami nawiązuje się w drodze mianowania lub umowy o pracę (Dz.U. poz. 1226). 
kluczowe było też stworzenie nowych zasad zatrudniania kadr urzędniczych w administracji nowego państwa. $\mathrm{O}$ ile oczywiste było to w przypadku pracowników samorządowych, z racji ich braku od 40 lat po likwidacji samorządu w 1950 roku, o tyle nie było to tak jednoznaczne w przypadku kadr urzędniczych administracji państwowej, z której miała dopiero wyodrębnić się nowa administracja rządowa.

Stąd też już od 1990 roku powstawanie nowych regulacji prawnych i ich dalsza ewolucja przebiegała zupełnie niezależnie w obu najbardziej sobie przeciwstawnych sektorach administracji publicznej: scentralizowanej administracji rządowej i zdecentralizowanej administracji samorządu terytorialnego. Poza nimi pozostał sektor administracji państwowej, którego kadry nadal regulowane były przepisami pragmatyki z 1982 roku mimo świadomości jej anachronizmu i nieprzystawalności do współczesnych potrzeb.

\section{Ewolucja statusu prawnego pracowników samorządowych}

Już w toku sejmowych prac nad projektami ustaw przywracających instytucję samorządu terytorialnego w Polsce zwrócono uwagę na konieczność ustawowego uregulowania zasad zatrudnia jego przyszłych pracowników, choć nie oznaczało to początkowo jednoznacznie odrębnej regulacji prawnej, skoro rozpatrywano poddanie ich wyłącznie Kodeksowi pracy lub dwuwariantowo zmodyfikowanej pragmatyce z 1982 roku Szczęśliwie jednak w komisjach a następnie samym sejmie zwyciężył pogląd o odrębności i samodzielności tej regulacji. Miał to być historyczny przełom, bowiem, jak wspomniano wcześniej, w dwudziestoleciu międzywojennym status pracowników samorządowych jedynie częściowo regulowany był przepisami ustaw ustrojowych, zaś zasadniczo statutami jednostek samorządu terytorialnego i pozostałymi ich uchwałami, a w krótkim okresie powojennym do likwidacji samorządu w 1950 roku problemem tym nowe władze nie zajmowały się, dążąc do wprowadzenia scentralizowanego ustroju rad narodowych.

Uchwalona w marcu 1990 roku pierwsza pragmatyka samorządowa ${ }^{62}$ nawiązywała jednak do pragmatyki z 1982 roku bezpośrednimi odwołaniami do jej przepisów oraz podobieństwem rozwiązań prawnych poszczególnych instytucji prawa urzędniczego, co poczytywano początkowo za zaletę z uwagi na podobieństwo funkcji spełnianych przez obie grupy urzędników przy jednoczesnej odrębności regulacyjnej ${ }^{63}$, z czasem zaczęto dostrzegać mankamenty takiego powiązania,

62 Ustawa z dnia 22 marca 1990 r. o pracownikach samorządowych (Dz.U. z 2001 r. Nr 142, poz. 1593).

${ }^{63}$ Zob. J. Korczak, Pozycja prawna pracownika samorzadowego w świetle przepisów ustawy o pracownikach samorzadowych (wybrane zagadnienia), „Człowiek i Środowisko” 1992, nr 1-2, t. 16 , s. 58 . 
zwłaszcza gdy kolejne nowelizacje pragmatyki urzędniczej zaczęły ją pozbawiać istotnych cech prawa urzędniczego ${ }^{64}$.

Początkowo pragmatyka regulowała jedynie status prawny pracowników urzędów gmin i urzędów ich jednostek pomocniczych, a także pracowników związków komunalnych i biur sejmików samorządowych, które funkcjonowały w latach 1990-1998 (art. 1 w brzmieniu z 1990 roku), dopiero ustawa o gospodarce komunalnej z 1996 roku rozszerzyła ten zakres na pracowników zakładów komunalnych ${ }^{65}$. Dalsze rozszerzenie nastąpiło w następstwie zmian ustrojowych z 1998 roku wraz z pojawieniem się pracowników zatrudnionych w powiatach i województwach samorządowych ${ }^{66}$.

Ustawa dzieliła pracowników na cztery kategorie w zależności od formy nawiązania stosunku pracy, tj. pracowników zatrudnionych na podstawie: wyboru (członków zarządów a po 2002 roku wójtów), powołania (skarbników i sekretarzy), mianowania (zajmujących stanowiska kierownicze i inne wskazane w statucie gminy, związku komunalnego lub regulaminie sejmiku do 1998 roku) i umowy o pracę (pozostali). Jak zwykle najwięcej wątpliwości budziło mianowanie i to do tego stopnia, że po reformie z 1998 roku nie wprowadzono go u samorządowych pracodawców powiatowych i wojewódzkich, a jednocześnie ograniczono mianowanie do stanowisk wyłącznie wskazanych w statucie gminy i związku, co powodowało $\mathrm{w}$ praktyce odstępowanie od mianowania. Jest to o tyle istotne, że pragmatyka w zasadniczej treści większości swoich przepisów była adresowana wyłącznie do mianowanych pracowników samorządowych (na 34 przepisy, 16 dotyczyło wyłącznie mianowanych pracowników), wprowadzając typowe instytucje prawa urzędniczego (np. stabilizacja zatrudnienia w art. 10-14, odpowiedzialność dyscyplinarna w art. 25). Przy tym jednak nie stosowano terminu „urzędnik” w odniesieniu do pracowników mianowanych, natomiast w wyniku nowelizacji z 2005 roku ${ }^{67}$ wprowadzono nowy sposób klasyfikacji pracowników samorządowych oparty na kategorii stanowisk urzędniczych i kierowniczych urzędniczych bez powiązania $\mathrm{z}$ formą nawiązania stosunku pracy, za to łącząc go z nową instytucją prawa urzędniczego - jawnym, otwartym i konkurencyjnym naborem

${ }^{64}$ Zob. J. Korczak, Ewolucja statusu pracowników samorządowych, [w:] Studia nad samorządem terytorialnym, red. A. Błaś, Wrocław 2002, s. 208.

65 Dokonano tego w art. 20 Ustawy z dnia 20 grudnia 1996 r. o gospodarce komunalnej (Dz.U. z 2017 r. poz. 827 ze zm.).

66 Na mocy art. 11 Ustawy z dnia 29 grudnia 1998 r. o zmianie niektórych ustaw w związku z wdrożeniem reformy ustrojowej państwa (Dz.U. Nr 162, poz. 1126 ze zm.).

${ }^{67}$ Ustawa z dnia 6 maja 2005 r. o zmianie ustawy o pracownikach samorządowych, ustawy o samorządowych kolegiach odwoławczych i ustawy o systemie oświaty (Dz.U. Nr 122, poz. 1020). O skutkach tej nowelizacji zob. J. Korczak, Urzędnik samorządowy - nowa instytucja polskiego prawa samorządowego, [w:] Sprawność działania administracji samorzadowej. VII Doroczna Konferencja Stowarzyszenia Edukacji Administracji Publicznej. Sandomierz, 21-23 maja 2006 r., red. E. Ura, Rzeszów 2006, s. 255-274. 
na wolne stanowisko urzędnicze, realizując tym samym dyrektywę otwartego dostępu do służby publicznej na równych zasadach z art. 60 Konstytucji RP ${ }^{68}$.

Negatywne doświadczenia w stosowaniu pragmatyki samorządowej z 1990 roku wyrażające się 19 jej nowelizacjami, które nie przynosiły jednak zadowalającej poprawy, doprowadziły do zastąpienia jej nową pragmatyką z listopada 2008 roku $^{69}$. Pragmatyka z 2008 roku wyraźnie w art. 1 akcentuje swoje związki z prawem pracy a nie prawem urzędniczym, ponadto zrezygnowano w niej z mianowania urzędników samorządowych, pozostawiając jedynie wybór jako formę zatrudnienia dla członków zarządów województw i powiatów oraz wójtów gmin, burmistrzów i prezydentów miast oraz członków zarządów związków komunalnych, a także zarządów dzielnic miasta stołecznego, a powołanie dla skarbników i zastępców organów wykonawczych gmin (art. 4 ust. 1). Nowością było zinstytucjonalizowanie swoistej praktyki samorządowej zatrudniania doradców i asystentów marszałków, starostów i wójtów, burmistrzów (wcześniej zatrudniano ich na różnych stanowiskach, ale faktycznie wykonywali takie czynności) przez wskazanie odrębnej kategorii stanowisk (art. 4 ust. 2 pkt 2) z jednoczesnym ograniczeniem ich liczby oraz okresem zatrudnienia — na czas pełnienia funkcji piastunów funkcji (art. 17). Jednak w 2017 roku specjalną regulacją usunięto te przepisy, dowodząc, że tzw. gabinety polityczne oparte są wyłącznie na partyjnych powiązaniach z osobami piastunów funkcji i prowadzą do marnotrawstwa publicznych pieniędzy ${ }^{70}$, co oczywiście ponownie powoduje ukrywanie ich zatrudnienia na innych stanowiskach.

W ustawie utrzymano przyjęty w 2005 roku podział na stanowiska urzędnicze i kierownicze urzędnicze oraz stanowiska pomocnicze i obsługowe, zaś poza nimi stanowiska wspomnianych wcześniej pracowników zatrudnianych na podstawie wyboru i powołania (art. 4 ust. 2). Przy czym ustawa nie wskazała kryteriów tego rozróżnienia poza wskazaniem wymogów kwalifikacyjnych oraz koniecznością zatrudnienia wyłącznie w wyniku naboru na wolne stanowiska urzędnicze (art. 6 ust. 3 i 4 oraz art. 11-15). Dopiero rozporządzenie wykonawcze w sprawach wynagradzania pracowników zawiera wykazy stanowisk urzędniczych i kierowniczych urzędniczych ${ }^{71}$, ale ich układ nie jest ani konsekwentny, ani logiczny ${ }^{72}$.

68 Konstytucja Rzeczypospolitej Polskiej z dnia 2 kwietnia 1997 r. (Dz.U. Nr 78, poz. 483 ze zm.).

69 Ustawa z dnia 21 listopada 2008 r. o pracownikach samorządowych (Dz.U. z 2018 r. poz. 1260 ze zm.). O przyczynach uchwalenia nowej ustawy i istotnych różnicach między obu pragmatykami zob. J. Korczak, Profesjonalizacja kadr administracji publicznej z perspektywy nowych regulacji samorzadowego prawa urzędniczego, [w:] Władza, obywatele, informacja. Ku nowemu porządkowi prawnemu. Księga pamiątkowa ku czci profesor Teresy Górzyńskiej, red. I. Lipowicz, Warszawa 2014, s. 175-187.

70 Ustawa z dnia 15 września 2017 r. o zmianie ustawy o pracownikach samorządowych (Dz.U. poz. 1930) wraz z uzasadnieniem do druku 1324.

71 Rozporządzenie Rady Ministrów z dnia 15 maja 2018 r. w sprawie wynagradzania pracowników samorządowych (Dz.U. poz. 936), zał. nr 3, tabela 2.

72 Zasadniczo obecne rozporządzenie nie różni się pod tym względem od poprzednich, m.in. z 2005 r., którego analizę krytyczną przeprowadziłem w: J. Korczak, Urzędnik samorządowy..., s. 263-269, wykazując szereg nieścisłości i wątpliwości co do poprawności tego wykazu. 
Pragmatyka zrezygnowała z większości klasycznych instytucji prawa urzędniczego, nie przewiduje zatem żadnych rozwiązań o charakterze stabilizującym, bowiem takiego charakteru nie ma przecież umowa o pracę na czas nieokreślony, pracownicy poddani są wyłącznie kodeksowej odpowiedzialności pracowniczej, a nie dyscyplinarnej, poza zróżnicowaniem wg grup zaszeregowania brak jakichkolwiek innych typowych dla prawa urzędniczego stopni czy kategorii. Mimo braku korpusowego charakteru zatrudnienia pozostawiono jedną z jego cech dyspozycyjność - przejawiającą się w możliwości przenoszenia do innych jednostek organizacyjnych oraz powierzania innych obowiązków (art. 21-23). Zwrócono ponadto uwagę na zawodowy charakter wykonywania pracy na stanowiskach urzędniczych nie tylko w przywołanej instytucji naboru konkurencyjnego, ale też okresowych ocen kwalifikacyjnych z selekcyjnym skutkiem ich negatywnego wyniku (art. 27) i możliwością awansu (art. 20).

\section{Ewolucja regulacji służby cywilnej w Polsce}

W drugiej połowie lat 80 . rozpoczęła się na nowo dyskusja nad kształtem i stanem regulacji statusu prawnego pracowników administracji publicznej. Głosy krytyczne, opierając się na negatywnych doświadczeniach praktyki stosowania pragmatyki urzędniczej (zbyt często w praktyce pomijano nakaz mianowania urzędników państwowych, dosyć szybko zabrakło środków finansowych na systematyczne podnoszenie kwalifikacji pracowników już zatrudnionych, prawie zupełnie zaniechano aplikowania nowo przyjmowanych urzędników), zaczęły zdecydowanie przeważać i jednoznacznie wskazywać potrzebę nie tyle nowelizacji ustawy, ile raczej potrzebę zupełnie nowej regulacji budującej korpus służby cywilnej. Potrzebę uzasadniano ustrojowo rozdzieleniem administracji państwowej od odbudowywanej równolegle z samorządem terytorialnym począwszy od 1990 roku administracji rządowej ${ }^{73}$. Zwieńczenie tych prac nastąpiło dopiero w 1996 roku, kiedy uchwalono — jak się potem okazało pierwszą z czterech ustawę o służbie cywilnej ${ }^{74}$. Opóźnienie miało podłoże wyłącznie polityczne i związane było z często zmieniającymi się rządami $^{75}$, z których każdy miał własne koncepcje na przyszłą służbę cywilną.

Ustawa, choć utrzymana była w nurcie publicznoprawnego charakteru, nawiązując do swej poprzedniczki z 1922 roku, wprowadzała zmiany wręcz rewolucyjne i dotychczasowemu polskiemu prawu urzędniczemu nieznane, jak chociażby prze-

73 Zapoczątkowała ten proces Ustawa z dnia 22 marca 1990 r. o terenowych organach rządowej administracji ogólnej (Dz.U. Nr 21, poz. 123 ze zm.).

74 Ustawa z dnia 5 lipca 1996 r. o służbie cywilnej (Dz.U. Nr 89, poz. 402 ze zm.).

75 W okresie od przełomu z 1989 r. do dnia uchwalenia ustawy było 6 składów Rady Ministrów. 
niesienie urzędnika w stan nieczynny (art. 40) czy udzielanie płatnego urlopu dla poratowania zdrowia w wymiarze do 6 miesięcy (art. 62). W art. 1 formułowała po raz pierwszy cel swojego uchwalenia, który mimo późniejszych nowelizacji i kolejnych regulacji przetrwał w niezmienionej postaci do dzisiaj, a w $1997 \mathrm{roku}$ uległ nawet konstytucjonalizacji, stając się treścią art. 153 ust. 1 Konstytucji RP. Zgodnie z nim w celu zapewnienia zawodowego, rzetelnego, bezstronnego i politycznie neutralnego wykonywania zadań państwa tworzy się w urzędach administracji rządowej korpus służby cywilnej. Ustawa z 1996 roku powoływała korpus moniczny, składający się wyłącznie z urzędników służby cywilnej zatrudnianych wyłącznie na podstawie mianowania (art. 2) na czas nieokreślony, a w przypadkach przewidzianych ustawą także określony (art. 27). Zatrudnienie cechowała stabilizacja wyrażająca się ograniczeniem możliwości rozwiązywania stosunku za wypowiedzeniem i bez wypowiedzenia (art. 44) lub wygaśnięciem stosunku w określonych okolicznościach (art. 43).

Publicznoprawny charakter stosunku służbowego wiązał się z dużą dyspozycyjnością wyrażoną w klasycznych instytucjach prawa urzędniczego: przenoszenia urzędnika do innego urzędu, w tym także do innej miejscowości (art. 35-37), przenoszenia w stan nieczynny na okres do 1 roku z możliwością swobodnego dysponowania urzędnikiem w tym okresie (art. 40) oraz zawieszeniem obligatoryjnym (art. 41) i fakultatywnym (art. 42). Urzędników poddano odpowiedzialności dyscyplinarnej przed dwuinstancyjnymi komisjami dyscyplinarnymi złożonymi z członków korpusu (rozdział 9) z najsurowszą karą w postaci wydalenia ze służby, co praktycznie mogło wyeliminować daną osobę ze służby na zawsze (pozwala tak wnioskować analiza art. $79 \mathrm{w}$ zakresie zatarcia tej kary dyscyplinarnej).

Podobnie jak w 1922 roku dokonano podziału urzędników, tym razem na 4 kategorie oznaczone literowo w oparciu o kryterium rodzaju wykonywanej funkcji i zadań wraz z dobranymi do ich charakteru kwalifikacjami, których spełnienie warunkowało zaliczenie do kategorii, przy czym najwyższa kategoria A wiązała się z najwyższymi kwalifikacjami, co do formalnego wykształcenia, jak i doświadczenia, a odpowiednio kategorie B i C wiązały się z kwalifikacjami niższymi, zaś kategoria S dotyczyła kwalifikacji specjalistycznych (art. 28). Przy czym nabór do służby w postępowaniu kwalifikacyjnym prowadzonym przez Komisję Kwalifikacyjną organizowany był osobno do każdej kategorii (art. 29).

Korpus został zorganizowany wewnętrznie w taki sposób, aby mimo podporządkowania go Prezesowi Rady Ministrów jako zwierzchnikowi (art. 153 ust. 2 Konstytucji RP) zapewnić neutralność polityczną. W tym celu ustawa z 1996 roku przewidywała organy korpusu w postaci organów kolegialnych: Rady Służby Cywilnej, komisji (kwalifikacyjna, odwoławczej i dwóch instancji komisji dyscyplinarnych) oraz monokratycznych: Szefa Służby Cywilnej i dyrektorów generalnych urzędów. Prezes Rady Ministrów powoływał członków Rady na sześcioletnią kadencję (art. 8 i 9), zaś członków Komisji Kwalifikacyjnej, Komisji Odwoławczej i Wyższej Komisji Dyscyplinarnej na wniosek Szefa Służby Cywilnej i w poro- 
zumieniu z dyrektorami generalnymi (art. 14). Zwłaszcza koncepcja dyrektorów generalnych zasługuje na uwagę, bowiem to oni bezpośrednio realizowali zasadę neutralności w poszczególnych urzędach, jako że, w odróżnieniu od rozwiązań z lat poprzednich, zatrudnianie urzędników w poszczególnych urzędach — choć samego aktu mianowania dokonywał Szef Służby Cywilnej — powierzono dyrektorom, pozbawiając tym samym piastunów organów administracji rządowej (ministrów i wojewodów) ich wpływu na politykę kadrową (art. 32) ${ }^{76}$.

To jednak instytucja dyrektorów generalnych stała się przyczyną niepowodzenia tej ustawy, jako że już na początku obowiązywania ustawy doszło do nieprawidłowości właśnie w mianowaniu dyrektorów generalnych urzędów, co ujawniła najpierw Teresa Rabska będąca członkiem pierwszej Rady Służby Cywilnej ${ }^{77}$, a co potwierdził późniejszy Raport z przeprowadzonej analizy i oceny tworzenia służby cywilnej (sierpień 1996-wrzesień 1997) ${ }^{78}$, który wywołał reakcje Jana Szachułowicza, pierwszego w historii Szefa Służby Cywilnej ${ }^{79}$, oraz przyjęcie uchwały Rady Służby Cywilnej ${ }^{80}$. W konsekwencji J. Szachułowicz złożył rezygnację podobnie jak kilku członków Rady Służby Cywilnej, a Jerzy Buzek, ówczesny premier po wyborach z 1997 roku, po rozwiązaniu w lipcu 1998 roku Komisji Kwalifikacyjnej zablokował nabór do korpusu, inicjując jednocześnie nowe prace legislacyjne.

Prace te przebiegały $\mathrm{w}$ atmosferze silnego sporu politycznego nie tylko o kształt nowej ustawy, ale w ogóle o ideę służby cywilnej ${ }^{81}$, w efekcie uchwalona w grudniu 1998 roku druga $\mathrm{z}$ kolei ustawa ${ }^{82}$ przyjęła zupełnie odmienny model służby cywilnej, odchodząc od modelu kariery służbowej na rzecz modelu mieszanego - kariery służbowej z elementami modelu stanowiskowego. Przede wszystkim zaś odchodząc od korpusu monicznego na rzecz korpusu dualistycz-

76 Załącznik nr 1 Wykaz stanowisk w stużbie cywilnej w Kancelarii Prezesa Rady Ministrów oraz urzędach naczelnych i centralnych organów administracji rządowej oraz załącznik nr 2 Wykaz stanowisk $w$ stużbie cywilnej $w$ urzędach terenowych organów administracji rzadowej administracji ogólnej do Rozporządzenia Prezesa Rady Ministrów z dnia 17 września 1997 r. w sprawie określenia wykazu stanowisk w służbie cywilnej i stanowisk w służbie cywilnej, które mogą być wyznaczane wyłącznie urzędnikom służby cywilnej, oraz wyjątków od tej zasady (Dz.U. Nr 109, poz. 707). Szczegółowy zakres czynności dyrektorów w tym zakresie zawierał § 1 rozporządzenia Prezesa Rady Ministrów z dnia 30 września 1997 r. w sprawie szczegółowego zakresu działania dyrektora generalnego urzędu (Dz.U. Nr 124, poz. 788).

77 T. Rabska, Kontrowersje wokót stużby cywilnej i dyrektorów generalnych urzędów, „Rzeczpospolita” 1997, nr 49 (4606), s. 15.

78 „Biuletyn Służby Cywilnej” 1998, nr 4.

79 J. Szachułowicz, Uwagi do raportu, „Rzeczpospolita” 1998, nr 77 (4937), s. 8.

80 Kontrowersje te opisuje: J. Kornaś, Polska służba cywilna — problemy rozwoju, „Zeszyty Naukowe Uniwersytetu Ekonomicznego w Krakowie” 2009, nr 803, s. 28-33.

81 Oddają to publikacje z tego okresu: A. Bida, Po co komu stużba cywilna, „Rzeczpospolita” 1998, nr 55 (4915), s. 8; A.K. Kluczny, Komu przeszkadza stużba cywilna, „Rzeczpospolita” 1998, nr 70 (4930), s. 10; D. Długosz, Jaki system dla Polski, „Rzeczpospolita” 1998, nr 77 (4937), s. 8; M. Gintowt-Jankowicz, O stużbie cywilnej inaczej, „Rzeczpospolita” 1998, nr 77 (4937), s. 8.

82 Ustawa z dnia 18 grudnia 1998 r. o służbie cywilnej (Dz.U. z 1999 r. Nr 49, poz. 483 ze zm.). 
nego, który funkcjonuje do dzisiaj, polegającego na zatrudnieniu w korpusie obok urzędników także pracowników służby cywilnej (art. 3). Pod rządami tej ustawy zrezygnowano zatem z naboru do korpusu (ustawa nie przewidziała już wśród organów korpusu Komisji Kwalifikacyjnej i Komisji Odwoławczej) na rzecz naboru na wolne stanowisko urzędnicze dokonywanego przez dyrektora generalnego urzędu (art. 5 w zW. z art. 21).

Dualizm zaznaczył się też w zatrudnianiu pracowników na podstawie umowy o pracę (art. 24), którzy dopiero po spełnieniu warunków z art. 28 mogli ubiegać się o mianowania na urzędnika służby cywilnej, którego dokonywał Szef Służby Cywilnej. Tym samym mianowanie przestało pełnić formę nawiązania stosunku pracy, a stało się formą przekształcenia stosunku umownego w stosunek z mianowania (art. 37), połączone było natomiast z nadaniem pierwszego z dziewięciu stopni służbowych — nowości w stosunku do ustawy z 1996 roku — które poza numeracją nie nosiły żadnych nazw, a z którymi wiązał się nowy składnik wynagrodzenia urzędników w postaci dodatku za stopień służbowy (art. 79). Urzędnicy mogli ubiegać się o przeniesienie na wyższe stanowiska w służbie cywilnej (rozdział 4), jako nowe kategorie stanowisk urzędniczych, w drodze postępowania konkursowego. Do katalogu instytucji prawa urzędniczego ustawa z 1998 roku wprowadziła dwunastomiesięczną służbę przygotowawczą, której obowiązek odbywania nałożono na zatrudnianych po raz pierwszy w służbie cywilnej z uzależnieniem zatrudnienia na czas nieokreślony od wyników końcowych egzaminów i oceny kandydata (art. 25). Ustawa wprowadziła utrzymane do dzisiaj preferencje dla absolwentów utworzonej w 1991 roku Krajowej Szkoły Administracji Publicznej polegające na zastąpieniu konkurencyjnego naboru na wolne stanowisko urzędnicze wskazaniem przez Prezesa Rady Ministrów pierwszego stanowiska pracy w służbie cywilnej (art. 23), zwolnieniu ze służby przygotowawczej (art. 27) oraz mianowaniu absolwentów na urzędników służby cywilnej na podstawie wniosku o mianowanie z pominięciem postępowania kwalifikacyjnego (art. 30 ust. 2).

Dualizm korpusu przenosił się na stosowanie przepisów ustawy w zakresie poszczególnych instytucji prawa urzędniczego. Zatem tylko urzędnicy podlegali instytucji przenoszenia na inne stanowiska (art. 50), do innych urzędów w tym także położonych w innych miejscowościach (art. 51-54) w drodze decyzji administracyjnych podlegających postępowaniu instancyjnemu z sądową kontrolą włącznie w razie odwołania się urzędnika (art. 56). Podobnie tylko urzędnicy mogli być przenoszeni w stan nieczynny (art. 57). Również rozwiązania stabilizujące zatrudnienie przez szczególną ochronę trwałości stosunku pracy odnosiły się tylko do mianowanych urzędników (art. 60-63). Pracownicy służby cywilnej w tym zakresie podlegali wyłącznie przepisom Kodeksu pracy. Natomiast w zakresie zawieszania obligatoryjnego i fakultatywnego (art. 58 i 59) oraz odpowiedzialności dyscyplinarnej (rozdział 9) przepisy adresowane były do członków korpusu łącznie, różnicując jedynie katalogi kar dyscyplinarnych dla urzędników (art. 107 ust. 1) i dla pracowników (art. 107 ust. 2). 
Niestety stosowanie i tej ustawy nie było wolne od politycznych uwarunkowań i nacisków na przestrzeganie przepisów o naborze na wolne stanowiska ${ }^{83}$ zwłaszcza w odniesieniu do urzędników zajmujących w korpusie wyższe stanowiska. Przejawiało się to próbami ich obchodzenia nawet w drodze regulacji ustawowych $^{84}$, aż wreszcie doprowadziło do istotnego przełomu w 2006 roku, kiedy to uchwalono trzecią z kolei ustawę o służbie cywilnej ${ }^{85}$, ale $\mathrm{z}$ wyłączeniem dotychczasowych wyższych stanowisk w służbie cywilnej, które teraz jako wyższe stanowiska państwowe poddano odrębnej regulacji ustawowej ${ }^{86}$.

Ustawa z 2006 roku nie wprowadzała nowych rozwiązań z zakresu prawa urzędniczego, zrezygnowano natomiast z niektórych instytucji, jak przeniesienie w stan nieczynny, bezpłatne urlopowanie na czas pełnienia funkcji lub wykonania czynności niedozwolonych w korpusie, urlopu na poratowanie zdrowia, wydłużania okresu urlopu wypoczynkowego po przepracowaniu 10 lat w służbie. Ustawa z 2006 roku zaprzeczała neutralności politycznej korpusu już choćby przez fakt likwidacji dwóch kluczowych organów: Rady Służby Cywilnej, którą teraz zastąpić miała Rada Służby Publicznej przy Prezesie Rady Ministrów, ale związana z państwowym zasobem kadrowym, zatem nie służąca celom korpusowym (rozdział V ustawy o państwowym zasobie kadrowym), i Szefa Służby Cywilnej, w którego zastępstwie korpusem miał zarządzać Szef Kancelarii Prezesa Rady Ministrów, czyli jeden z najbardziej politycznie legitymizowanych funkcjonariuszy publicznych (art. 8 ust. 3). Nie można nie zauważyć, że termin „państwowy zasób kadrowy" użyty dla regulacji, która odnosiła się wyłącznie do stanowisk kierowniczych i wysokich stanowisk urzędniczych w strukturach administracji rządowej był nieuprawiony, skoro jednocześnie nie wprowadzano żadnych zmian dotyczących stanowisk urzędniczych w sektorze administracji państwowej. Był zarazem przykładem błędu poznawczego utożsamiania administracji rządowej z państwem, które przecież reprezentowane jest w każdym sektorze.

83 Co doprowadziło do ważnej nowelizacji Ustawy z dnia 17 czerwca 2005 r. o zmianie ustawy o służbie cywilnej oraz niektórych innych ustaw (Dz.U. Nr 132, poz. 1110), wprowadzają bardzo szczegółowe uregulowania ogłaszania naboru, jego przeprowadzania oraz ogłaszania wyników — zob. na ten temat J. Korczak, Procedury naboru do stużby cywilnej — biurokratyzacja czy modelowa biurokracja, [w:] Biurokracja - Bureaucracy. III Międzynarodowa Konferencja Naukowa, Krynica Zdrój, 2-4 czerwca 2006 r., red. J. Łukasiewicz, Rzeszów 2006, s. 290-301.

${ }^{84} \mathrm{Na}$ mocy art. 31 pkt 10 Ustawy z dnia 21 grudnia $2001 \mathrm{r}$. o zmianie ustawy o organizacji i trybie pracy Rady Ministrów oraz o zakresie działania ministrów, ustawy o działach administracji rządowej oraz o zmianie niektórych ustaw (Dz.U. Nr 154, poz. 1800) wprowadzono do ustawy art. 144a pozwalający okresowo obsadzać wyższe stanowiska osobami spoza korpusu, co spowodowało złożenie do Trybunału Konstytucyjnego wniosku o zbadanie zgodności tej nowelizacji z art. 153 Konstytucji, a w jego konsekwencji Trybunał wyrokiem K 9/02 z dnia 12 grudnia 2002 r. stwierdził niezgodność tej regulacji z przepisami Konstytucji (Dz.U. Nr 238, poz. 2025).

${ }^{85}$ Ustawa z dnia 24 sierpnia 2006 r. o służbie cywilnej (Dz.U. Nr 170, poz. 1218 ze zm.).

86 Ustawa z dnia 24 sierpnia 2006 r. o państwowym zasobie kadrowym i wysokich stanowiskach państwowych (Dz.U. Nr 170, poz. 1217 ze zm.). 
Przedterminowe rozwiązanie sejmu i zmiana układu politycznego po wyborach z 2007 roku zaowocowały w przypadku prawa urzędniczego dwoma ważnymi ustawami z dnia 21 listopada 2008 roku: omawianą już pragmatyką samorządową i czwartą z rzędu ustawą o służbie cywilnej ${ }^{87}$. Jej rolą było odwrócenie negatywnych skutków ustawy z 2006 roku, uchylała zatem nie tylko tę ustawę, ale też ustawę o państwowym zasobie kadrowym, przywracając jednolitość regulacji w jednym akcie prawnym pragmatyki urzędniczej w sektorze administracji rządowej. Ustawa przywróciła zatem organizację korpusu służby cywilnej, gdy idzie o Szefa Służby Cywilnej (art. 10), choć pozbawionego własnego urzędu, skoro obsługę zapewnia mu jedynie departament w Kancelarii Prezesa Rady Ministrów (art. 14) oraz Radę Służby Cywilnej (art. 19-23). Utrzymano sprawdzone już instytucje prawa urzędniczego kształtujące istotę korpusu, jak np. zawodowy charakter wykonywania zadań (oparty na otwartym i konkurencyjnym naborze na wolne stanowiska urzędnicze, służbie przygotowawczej, postępowaniu kwalifikacyjnym do mianowania na urzędnika oraz okresowych ocenach kwalifikacyjnych), neutralność polityczną (związaną z zakazami manifestowania poglądów politycznych, uczestnictwem w strajkach, aktywnością w organach samorządu terytorialnego i partiach politycznych — art. 78), wysoką dyspozycyjność urzędnika (wynikającą z możliwości przenoszenia na inne stanowiska i do innych urzędów nawet położonych w innych miejscowościach — art. 62-66).

Przywrócono również wyższe stanowiska w służbie cywilnej (art. 52) z konkursowym i otwartym trybem naboru (art. 57), jak się jednak okazało nie na długo, oto bowiem po wyborach w 2015 roku dokonano nowelizacji ustawy z 2008 roku $^{88}$, w wyniku której obecnie stanowiska te są obejmowane w drodze powołania w rozumieniu art. 68 Kodeksu pracy (art. 53a), przy czym powołanie nie jest poprzedzone żadnym postępowaniem kwalifikacyjnym ${ }^{89}$. Nie tylko w ten sposób złamano konstytucyjną zasadę neutralności politycznej tej kategorii stanowisk, ale też ponownie Radę Służby Cywilnej zastąpiono Radą Służby Publicznej w pełni zależną od Prezesa Rady Ministrów (art. 19-21) ${ }^{90}$, przy okazji również

87 Ustawa z dnia 21 listopada 2008 r. o służbie cywilnej (Dz.U. z 2018 r. poz. 1559).

${ }^{88}$ Ustawa z dnia 30 grudnia 2015 r. o zmianie ustawy o służbie cywilnej oraz niektórych innych ustaw (Dz.U. z 2016 r. poz. 34).

89 Wnioskodawcy nowelizacji krytykowali system naboru konkurencyjnego jako niepożądany w przypadku stanowisk szczególnie związanych ,z wykonywaniem polityki rządu” i dlatego w jego miejsce proponowali zatrudnienie „w sposób elastyczny i mniej sformalizowany” — druk nr 119 z dnia 15 grudnia 2015 r., źródło: http://www.sejm.gov.pl/Sejm8.nsf/PrzebiegProc.xsp?nr=119 (dostęp: 4.12.2016).

90 Ocenę tej nowelizacji zob. J. Korczak, Antywartość w prawie administracyjnym jako zamierzony skutek legislacji, [w:] Antywartość w prawie administracyjnym. VI Krakowsko-Wrocławskie Spotkania Administratywistów, red. A. Błaś, Warszawa 2016, s. 146-157. 
z naruszeniem konstytucyjnych zasad państwa prawa pozbyto się wielu urzędników służby cywilnej zajmujących wyższe stanowiska w dniu wejścia w życie tej nowelizacji ${ }^{91}$.

\section{Uwagi końcowe}

W stuletniej historii państwa polskiego po odzyskaniu niepodległości w 1918 roku okres obowiązywania prawa urzędniczego w jego najpełniejszej postaci jest stosunkowo krótki. Przyjęta w 1922 roku pierwsza polska pragmatyka urzędnicza, choć formalnie obowiązywała do końca 1974 roku, w nowych warunkach ustrojowych państwa po II wojnie światowej była pozbawiona swoich istotnych wartości i stosowana w praktyce do coraz węższego kręgu adresatów. Wobec niej coraz bardziej konkurencyjne stawały się regulacje, których celem było odejście od prawa urzędniczego do prawa pracy, co szczególnie entuzjastycznie oceniali apologeci nowego ustroju ${ }^{92}$. Zwieńczeniem tego procesu była oczywiście kodyfikacja prawa pracy w 1974 roku i od tej pory nawet jeśli udawało się powrócić do odrębnych pragmatyk urzędniczych (państwowej z 1982 roku, służby cywilnej z lat 1996, 1998, 2006 i 2008 oraz obu samorządowych z 1990 i 2008), to są to akty niesamodzielne, bowiem każda z pragmatyk w jakiejś części spraw zatrudnienia urzędników wymaga zastosowania przepisów Kodeksu pracy, pomijając konieczność stosowania dodatkowo innych ustaw administracyjnego prawa ustrojowego ${ }^{93}$ lub materialnego ${ }^{94}$.

Bez wątpienia niegdysiejsze rozważania o możliwości rozbudowy korpusowego charakteru zatrudnienia polskich urzędników ${ }^{95}$ na wszystkie trzy sektory

91 Zob. J. Korczak, Sytuacja prawna osoby zajmującej wyższe stanowisko urzędnicze w stużbie cywilnej z perspektywy zmian $w$ ustawie o stużbie cywilnej, [w:] Jednostka wobec działań administracji publicznej, red. E. Ura, E. Feret, S. Pieprzny, Rzeszów 2016, s. 284-305.

92 M. Jaroszyński w: Stużba państwowa w administracji, [w:] M. Jaroszyński, M. Zimmermann, W. Brzeziński, Polskie prawo administracyjne. Część ogólna, Warszawa 1956, s. 301 pisał o tendencji do „zrównania sytuacji pracownika służby państwowej z sytuacją ogółu pracowników”.

93 Przykładowo status burmistrza miasta w Polsce regulują aż trzy ustawy: pragmatyka samorządowa z 2008 r.; Ustawa z dnia 8 marca 1990 r. o samorządzie gminnym (Dz.U. z 2018 r. poz. 994 ze zm.), czyli ustawa ustrojowa, a także Ustawa z dnia 5 stycznia 2011 r. — Kodeks wyborczy (Dz.U. z 2018 r. poz. 754), czyli ordynacja wyborcza.

94 Przykładowo status powiatowego inspektora nadzoru budowlanego obok pragmatyki urzędniczej z 2008 r. także Ustawa z dnia 7 lipca 1994 r. — Prawo budowlane (Dz.U. z 2018 r. poz. 1202), czyli ustawa prawa materialnego; z kolei status wojewódzkiego konserwatora zabytków reguluje również pragmatyka urzędnicza (ustawa o służbie cywilnej), jak i prawo materialne Ustawa z dnia 23 lipca 2003 r. o ochronie zabytków i opiece nad zabytkami (Dz.U. z 2017 r. poz. 2187 ze zm.).

$95 \mathrm{O}$ znaczeniu korpusowego charakteru organizacji służby cywilnej zob. J. Korczak, $W k w e-$ stii potrzeby wyodrębnienia prawa urzędniczego i korpusowego charakteru stużby publicznej, 
administracji publicznej — państwowy, rządowy i samorządowy — straciły swój sens wobec działań i zaniechań polskiego ustawodawcy. Korpus służby cywilnej został mocno osłabiony po nowelizacjach z 2016 roku i trudno prognozować poprawę tego stanu. Przyjęta w 2008 roku nowa pragmatyka samorządowa ostatecznie przekreśliła szanse na samorządową służbę cywilną ${ }^{96}$, a brak pomysłu na kadrę urzędniczą $\mathrm{w}$ administracji państwowej podsumowuje negatywnie dotychczasowe rozważania o konsolidacji wszystkich trzech korpusów urzędniczych.

Przedwcześnie zmarła Teresa Górzyńska - jedna z czołowych przedstawicielek doktryny polskiego prawa urzędniczego - wiele ze swych wypowiedzi w publikacjach artykułowych i monograficznych poświęcała stanowi i kierunkom przekształceń prawa urzędniczego, oceniając je krytycznie. Szczególnym tego wyrazem jest wydana już pośmiertnie, niedokończona monografia, w samym tytule której zawiera się teza o kryzysie tożsamości, jaki przechodzi polskie prawo urzędnicze $^{97}$. Sądzę, że przeprowadzona powyżej analiza przemian w polskim prawie urzędniczym, zwłaszcza w ostatnich dekadach, tezę tę w pełni uzasadnia, co niestety przekłada się negatywnie na stan kadr polskiej administracji publicznej ${ }^{98}$.

\section{Bibliografia}

Bereza A., Pozycja monarchy w Księstwie Warszawskim, „Studia Iuridica Lublinensia” 2012, nr 18. Bida A., Po co komu stużba cywilna, „Rzeczpospolita” 1998, nr 55 (4915).

Długosz D., Jaki system dla Polski, „Rzeczpospolita” 1998, nr 77 (4937).

Gintowt-Jankowicz M., O stużbie cywilnej inaczej, „Rzeczpospolita” 1998, nr 77 (4937).

Górzyńska T., Polskie prawo urzędnicze — kryzys tożsamości?, Warszawa 2016.

Grosse T.G., Czy w Polsce powinna powstać samorzadowa służba cywilna?, „Samorząd Terytorialny" 2000, $\mathrm{nr} 7-8$.

Iserzon E., Prawo administracyjne, Warszawa 1968.

Itrich-Drabarek J., Mroczka K., Samorzadowa stużba cywilna w Polsce - fakty i mity w świetle wyników badań, „Zarządzanie Publiczne” 2015, nr 4.

Jaroszyński M., Stużba państwowa w administracji, [w:] M. Jaroszyński, M. Zimmermann, W. Brzeziński, Polskie prawo administracyjne. Część ogólna, Warszawa 1956.

„Zeszyty Naukowe Uniwersytetu Szczecińskiego. Ekonomiczne problemy usług” 2009, nr 45, s. 299-308.

96 Zob. cykl artykułów: T.G. Grosse, Czy w Polsce powinna powstać samorządowa służba cywilna?, „Samorząd Terytorialny” 2000, nr 7-8; T. Mordel, Uwagi o potrzebie samorzadowej stużby cywilnej, „Samorząd Terytorialny” 2002, nr 7-8; T. Mordel, Samorządowa stużba cywilna. O potrzebie normatywnych gwarancji profesjonalizmu pracowników urzędów samorządowych, „Służba Cywilna” jesień-zima 2004/2005, nr 9; J. Itrich-Drabarek, K. Mroczka, Samorzadowa stużba cywilna w Polsce — fakty i mity w świetle wyników badań, „Zarządzanie Publiczne” 2015, nr 4, s. 7-22.

97 T. Górzyńska, Polskie prawo urzędnicze - kryzys tożsamości?, Warszawa 2016.

98 Zob. J. Korczak, Stan kadr administracji publicznej z perspektywy ogólnokrajowej i regionalnej, „Studia Prawa Publicznego” 2017, nr 1, s. 9-24. 
Jaśkiewicz W., Pracownicy administracji, [w:] System Prawa Administracyjnego, red. J. Jendrośka, t. 2, Wrocław 1977.

Jaśkiewicz W., Stosunek stużbowy, a stosunek pracy, „Ruch Prawniczy i Ekonomiczny” 1960, nr 2.

Jaśkiewicz W., Studia nad sytuacja prawna pracowników państwowych, t. 2. Socjalistyczna służba państwowa PRL — ZSRR, Poznań 1966.

Jaśkiewicz W., Sytuacja prawna pracowników administracji państwowej, [w:] Pracownicy administracji w PRL, red. J. Łętowski, Wrocław 1984.

Kluczny A.K., Komu przeszkadza stużba cywilna, „Rzeczpospolita” 1998, nr 70 (4930).

Korczak J., Antywartość w prawie administracyjnym jako zamierzony skutek legislacji, [w:] Antywartość w prawie administracyjnym. VI Krakowsko-Wrocławskie Spotkania Administratywistów, red. A. Błaś, Warszawa 2016.

Korczak J., Ewolucja statusu pracowników samorządowych, [w:] Studia nad samorządem terytorialnym, red. A. Błaś, Wrocław 2002.

Korczak J., Kadry administracji publicznej wobec przeobrażeń we współczesnym prawie administracyjnym, [w:] Wspótczesne problemy administracji publicznej i prawa administracyjnego. Materiały z sesji naukowej na temat przeobrażeń we współczesnym prawie administracyjnym, Wrocław listopad 1997, red. A. Błaś, Wrocław-Poznań 1999.

Korczak J., Pojęcie urzędnika państwowego w ustawie o pracownikach urzędów państwowych, „Organizacja - Metody - Technika” 1984, nr 10.

Korczak J., Pozycja prawna pracownika samorzadowego w świetle przepisów ustawy o pracownikach samorzadowych (wybrane zagadnienia), „Człowiek i Środowisko” 1992, nr 1-2, t. 16.

Korczak J., Procedury naboru do stużby cywilnej — biurokratyzacja czy modelowa biurokracja, [w:] Biurokracja - Bureaucracy. III Międzynarodowa Konferencja Naukowa, Krynica Zdrój, 2-4 czerwca 2006 r., red. J. Łukasiewicz, Rzeszów 2006.

Korczak J., Profesjonalizacja kadr administracji publicznej z perspektywy nowych regulacji samorzadowego prawa urzędniczego, [w:] Władza, obywatele, informacja. Ku nowemu porzadkowi prawnemu. Księga pamiątkowa ku czci profesor Teresy Górzyńskiej, red. I. Lipowicz, Warszawa 2014.

Korczak J., Stan kadr administracji publicznej z perspektywy ogólnokrajowej i regionalnej, „Studia Prawa Publicznego" 2017, nr 1.

Korczak J., Status prawny pracowników samorzadowych w II i III RP, [w:] 20 lat samorządu terytorialnego w II i III Rzeczypospolitej. I Wydziałowa Konferencja Kót Naukowych Wydziału Prawa, Administracji i Ekonomii Uniwersytetu Wrocławskiego, red. J. Korczak, Wrocław 2010.

Korczak J., Sytuacja prawna osoby zajmującej wyższe stanowisko urzędnicze w służbie cywilnej z perspektywy zmian w ustawie o stużbie cywilnej, [w:] Jednostka wobec działań administracji publicznej, red. E. Ura, E. Feret, S. Pieprzny, Rzeszów 2016.

Korczak J., Urzędnik samorządowy - nowa instytucja polskiego prawa samorzadowego, [w:] Sprawność działania administracji samorzadowej. VII Doroczna Konferencja Stowarzyszenia Edukacji Administracji Publicznej. Sandomierz, 21-23 maja 2006 r., red. E. Ura, Rzeszów 2006.

Korczak J., $W$ kwestii potrzeby wyodrębnienia prawa urzędniczego i korpusowego charakteru służby publicznej, „Zeszyty Naukowe Uniwersytetu Szczecińskiego. Ekonomiczne problemy usług" 2009, nr 45.

Koredczuk J., Związek reform prawa cywilnego z reformami administracyjnymi w Księstwie Warszawskim, [w:] Cywilizacja administracji publicznej. Ksiega jubileuszowa z okazji 80-lecia urodzin prof. nadzw. UWr dra hab. Jana Jeżewskiego, red. J. Korczak, „Prace Naukowe Wydziału Prawa Administracji i Ekonomii Uniwersytetu Wrocławskiego. Seria: e-Monografie” nr 115, Wrocław 2018.

Kornaś J., Polska stużba cywilna - problemy rozwoju, „Zeszyty Naukowe Uniwersytetu Ekonomicznego w Krakowie”, nr 803, Kraków 2009. 
Kościołek J., Państwowa służba cywilna. Jednolity tekst pragmatyki i komentarz, Łódź 1947.

Kozłowski J., Administracja Wielkopolski pod pruskim zaborem 1793-1918, Poznań 2000.

Kuczyński T., Stelina J., Geneza i kierunki rozwoju prawa stosunków stużbowych w Polsce, [w:] System Prawa Administracyjnego, red. R. Hauser, Z. Niewiadomski, A. Wróbel, t. 11. Stosunek stużbowy, Warszawa 2011.

Langrod J.S., Stużba państwowa, [w:] K.W. Kumaniecki, J.S. Langrod, S. Wachholz, Zarys ustroju, postępowania i prawa administracyjnego w Polsce, Kraków-Warszawa 1939.

Laubert M., Die Verwaltung der Provinz Posen 1815-1847, Breslau 1923.

Lotz A., Geschichte des deutschen Beamtentums, Berlin 1914.

Mordel T., Samorządowa stużba cywilna. O potrzebie normatywnych gwarancji profesjonalizmu pracowników urzędów samorządowych, „Służba Cywilna” jesień-zima 2004/2005, nr 9.

Mordel T., Uwagi o potrzebie samorządowej stużby cywilnej, „Samorząd Terytorialny” 2002, nr $7-8$.

Rabska T., Kontrowersje wokół służby cywilnej i dyrektorów generalnych urzędów, „Rzeczpospolita" 1997, nr 49 (4606).

Szachułowicz J., Uwagi do raportu, „Rzeczpospolita” 1998, nr 77 (4937).

Święcicki M., Przedmiot prawa pracy, [w:] Podstawowe problemy prawa pracy, red. Z. Salwa, W. Szubert, M. Święcicki, Warszawa 1957.

Zieliński T., Problem stosunków służbowych a kodyfikacja prawa pracy w PRL, „Państwo i Prawo" 1974, nr 6.

\section{Centenary of Polish civil service law}

\section{Summary}

The article analyzes the legal regulations related to officers and employees working in the offices and organizational units of public administrations in Poland between 1918 and 2018. The results of the study were used to identify the main determinants of clerical law in the past century and to try to assess its consequences.

Keywords: civil service law, public official, administrative official, administration employee. 